Open Access

\title{
How do Chinese firms adjust their financial leverage: an empirical investigation using multiple GMM models
}

\author{
Ajid ur Rehman ${ }^{1 *}$, Man Wang ${ }^{1}$ and Sultan Sikandar Mirza ${ }^{2}$
}

\author{
* Correspondence: \\ ajid.rehman@gmail.com \\ ${ }^{1}$ School of Accounting, Dongbei \\ University of Finance and \\ Economics, Dalian, People's \\ Republic of China \\ Full list of author information is \\ available at the end of the article
}

\begin{abstract}
Background: Given the unique market setting and institutional environment of China, this study tries to investigate targeting behavior of Chinese firms towards leverage and the determinants of leverage policy in China at various levels.

Methods: For this purpose, we used an extensive set of data of 760 firms over a period from 2001 to 2013. To investigate the adjustment behavior towards target leverage policy, this study uses the GMM (generalized method of moments) models of Arellano and Bover (J Econ 68:29-51, 1995)/Blundell and Bond (Econ Rev 19:321-340, 2000) to estimate the adjustment behavior and adjustment speed towards a target level of leverage. The study finds that Chinese firms have a target level of leverage and firms tries to adjust to their target.

Results: We found that adjustment rate of Chinese state-owned enterprises is higher than Chinese non-state owned, indicating an aggressive leverage policy for SOEs (state-owned enterprises). Further, the study found that some firm-level factors like firm size and growth opportunities have significant and positive effect on firms leverage. Profitability and firm liquidity is found to have a negative relationship with firm leverage. At country level, GDP (gross domestic product) is found to have positive impact of firm leverage policy. The negative relationship of lending rate with leverage shows that firms in China reduce debt financing when lending rates in the market increase.
\end{abstract}

Conclusions: All these findings indicate significant policy implications for Chinese firms. At adjustment level, regulatory bodies should ensure that all firms are at ease while raising their debt and thus avoid a pecking order in lending policy. At industry level, institutions should try to curtail industry concentration to provide an equal ground of debt issuing to the firms.

Keywords: Target leverage, Multilevel determinants, GMM, Chinese firms

\section{Background}

To raise capital through debt or equity and to develop an optimal mix of capital structure is one of the most integral managerial decisions and has attracted most of the research since 1950s. A number of theories have been formulated to explain the capital structure of a firm. Various determinants of capital structure have been identified by traditional capital structure theories. Empirical work of Baker and Wurgler (2002) and Fama and French (2002) reported that growth opportunities, profitability, size,

(c) The Author(s). 2017 Open Access This article is distributed under the terms of the Creative Commons Attribution 4.0 International License (http://creativecommons.org/licenses/by/4.0/), which permits unrestricted use, distribution, and reproduction in any medium, provided you give appropriate credit to the original author(s) and the source, provide a link to the Creative Commons license, and indicate if changes were made. 
tangibility, ownership concentration, and nontax debt shield are the important determinants of capital structure decisions of a firm. Furthermore, according to market timing theory of capital structure, price of stock is also a significant factor to be considered in capital structure decisions, especially when the price is increasing. The manner in which a firm capital structure policy is changed and adjusted over time is dependent on the desires and influence of different stakeholders of a firm. Thus, Deesomsak et al. (2004) argue that it is very important to logically formulate a firm's characteristics both inside and inside a firm that can influence firm capital structure decision making. Numerous studies involved various factors; however, these studies did not study factors at a multilevel, i.e., firm level, industry level, and country level simultaneously. There exist studies which on the one hand considered industry factors, but lacked consideration for time effects along with cross-sectional influences. Some studies do included industry factors; however, their application was limited to dummy variables and lacked inclusion of some very important industry-specific factors like industry leverage, industry liquidity, and industry concentration (industry HHI). The only exception in this regard includes studies conducted by Kayo and Kimura (2011) and MacKay and Phillips (2005). Moreover, majority of studies focused on the capital structure of firms belonging to developed countries. Studies conducted across developing countries especially Asian countries lacked a comprehensive approach of studying capital structure at a multilevel. One exception in this connection is the study conducted by Kayo and Kimura (2011).

Numerous theories compete in explaining capital structure decisions of a firm. Trade off theory is based on firm-specific factors to explain the capital structure decisions. The statistical significance of these factors varies across different countries. Pecking order theory is based on information asymmetry to explain capital structure decisions. Explanations put forward by these theories are under debate, and it is very difficult to ascertain which of these theories better explain capital structure decisions. Empirical evidence from developed countries like UK and USA favor the trade-off theory in these countries while in developing nations of Asia, it is the pecking order theory which explains capital structure of firms in a better way (Pandey 2001; Fan and So 2004). Empirical evidence on capital structure belongs to various countries with China being a market of unique institutional characteristics (Guney et al. 2011). Thus, there is a need to solve the puzzle of which capital structure theory better explains the capital structure of Asian markets. There is an important study about capital structure decisions in Hong Kong (Fan and So 2004). They argue that firms listed in Hong Kong are influenced by the pecking order theory in their capital structure decisions. However, the pecking order theory is under debate both in Asian and in developed countries like USA and Europe (Frank and Goyal 2003).

China being the world's second largest economy provides a unique market setting in terms of institutional setting, development of capital markets, and ownership concentration. Chinese companies are highly concentrated in terms of ownership concentration. A single largest owner held about $36 \%$ of an average company share, while $52 \%$ shares are held by the five largest owners (Guo et al. 2013). Compared to western economies Chinese firms have a very unique ownership structure. Shares are divided into three categories, i.e., state, legal, and shares held by individuals under Chinese company law. Central and provincial governments and their respective ministries hold the state 
shares. State-owned and non-state-owned enterprises hold the legal entity shares. Individual investors hold the individual shares. Moreover, before 2004, shares of stateowned and legal entities could be traded in stock exchange. This situation is further complicated by the fact that control rights remain with the Chinese government. Shares held by state-owned shareholders exceed other shares held by other shareholders (individuals and non-state-owned enterprises (NSOEs)) in Chinese companies. Guo et al. (2013) reported that by the end of September 2006, the largest shareholders who hold $56 \%$ of shares were state shares controlled by the Chinese government and other state asset management companies.

Capital markets in China are young and less sophisticated as compared to other developed countries. Shanghai and Shenzan Stock exchanges were established in 1990, and it marks the beginning of securities market in China. China securities regulatory commission was introduced in 1992. Poncet et al. (2010) argue that capital market imperfections are prevalent in Chinese capital markets. Until 1998, the largest Chinese banks (most of them were state owned) were advised not to give credit to Chinese private companies. It was because of the low political stature of these companies. Since 1998, these impediments in financing due to political pecking order should have been alleviated. However, research evidence suggest that financing constraints for private Chinese companies are still there due to social and political factors (Huang 2003). Numerous research studies indicate that financial constraints are impediments to investment, growth, and survival of the company (Stein 2003; Hubbard 1997). This implies that Chinese firms (especially private firms) have fewer alternatives of debt financing. This environment of less financing alternatives makes this study more important from the point of view of firms raising greater equity due to higher liquidity.

Our econometric approach is based on the assumption that firms in China have a target level of capital structure and that firms' financing policy is influenced by multilevel determinants. To account for an institutional setting, we conducted separate analysis for state-owned and non-state-owned enterprises.

We used an extensive set of data of 760 firms over a period from 2001 to 2013. To investigate the adjustment behavior towards target leverage policy, this study uses the generalized method of moments (GMM) models of Arellano and Bover (1995)/Blundell and Bond (2000) to estimate the adjustment behavior and adjustment speed towards a target level of leverage. The study finds that Chinese firms have a target level of leverage, and firms try to adjust to their target. We found that the adjustment speed of Chinese state-owned enterprises (SOEs) is higher than Chinese NSOEs, indicating an aggressive leverage policy for SOEs. Further the study found that some firm-level factors like firm size and growth opportunities have significant and positive effect on firms leverage. Profitability and firm liquidity is found to have a negative relationship with leverage of the firm. At country level, gross domestic product (GDP) is found to have a positive impact on firm leverage policy. The negative relationship of lending rate with leverage showed that firms in China reduce the debt financing when lending rates in the market increase. The study further investigates the adjustment speed using the ownership concentration of the single largest shareholder. We also apply Elsas and Florysiak (2015) fractional-dependent variable dynamic panel data model to estimate the adjustment speed. All our findings are consistent and robust for the entire three GMM model used. All these findings indicate significant policy implications for 
Chinese firms. At adjustment level, regulatory bodies should ensure that all firms are at ease while raising their debt and thus avoid a pecking order of lending policy. At industry level, institutions should try to curtail industry concentration to provide an equal ground of debt issuing to the firms.

The remainder of this paper is organized as follows. Section "Literature review" discusses an extensive review of literature about the determinants of capital structure at various levels and the target adjustment of leverage policy. This is followed by data description, methodology, "Model specification," and the "Estimation strategy." "Discussion of results" provides extensive analysis of results with respect to adjustment speed of Chinese firms towards leverage and leverage's determinants at various levels. At the end, the "Conclusions" provides some policy implications.

The essence of capital structure decisions exists in the arguments put forwarded by Modigliani and Miller (1958). They argue that in ideal markets, business value is not influenced by firms' financing decisions. However, this is not the case in real markets. Due to existence of taxes, transaction costs, and other factors, financing decisions become relevant to business valuation. One important study in this regard is the study of Byoun and Xu (2013). They examined financing policy of debt-free firms. They found that debt-free firms have the ability to raise funds through highdividend payments. Dividend payment enables these firms to raise equity funds on flexible terms and also help them in maintaining good reputation in equity markets. This greatly reduces the agency costs of free cash flow. While analyzing financing decisions in Korean firms, Jung and Kim (2008) reported that firms having larger cash reserves have better chance of exploiting benefits of interest tax shield in Korea.

In the following section, we review both static and dynamic nature of two very famous theories of capital structure, i.e., trade-off theory and pecking order theory.

In his paper, Modigliani and Miller (1963) studied financing decisions of firms having tax exemption of interest payments on debt. Bradley et al. (1984) further report evidence in support of static trade-off theory. They argue that across different industries, firms tend to raise debt until a point is reached where tax shield becomes equal to marginal costs of debt financing which also include the financial distress premium due to increase probability of default. Thus, firms tend to achieve an optimal static debt level which is referred as target capital structure.

Bris et al. (2006) further argue that benefits of tax shield increases with increase in profitability, increase in tax rate, and decrease in depreciation. They estimated that costs associated with financial distress could be $2-20 \%$ of assets. Andrade and Kaplan (1998) empirically found financial distress costs to be $10-20 \%$ of assets. Jalilvand and Harris (1984) include transaction costs and other forms of market imperfections in their research study. This shows that capital structure is dynamic in nature, and if it does not correspond to a target level, there must be a convergence strategy to achieve a target capital structure. Thus, few important questions with regard to capital structure decisions might be how transaction costs influence capital structure? Secondly, what factors determines the speed of adjustment towards a target level of capital structure? How firms react to capital structure shocks? These implications extend the static approach of capital structure and form the foundation and framework for a dynamic capital structure policy. 
Dynamic trade-off theory of capital structure is tested by Frank and Goyal (2008) by using the target adjustment hypothesis. The target of capital structure varies across firms and is influenced by various exogenous and endogenous factors. Fischer et al. (1989) put forward a theory of dynamic capital structure choices and reported that leverage ratio is influenced by firm-specific factors. Flannery and Hankins (2007) come up with important findings that speed of adjustment depends upon the expenditure needed by a firm to adapt to a new capital structure policy and the deviation costs associated with the policy. They further report that adjustment costs are influenced by transaction cost and market valuation of equity, while costs of deviation from an optimal policy is a function of the probability of financial distress and level of tax shield of the firm. Leland and Toft (1996) put forward a dynamic model considering the endogeneity level of financial distress. They further explained the optimal level of leverage and debt maturity structure. Hennessy and Whited (2007), while analyzing the trade-off model in the presence of leverage and real investment, reported that leverage follows a path and decreases with liquidity. Leary and Roberts (2005) and Byoun (2008) argue that during adjustment, decisions to a target level of capital structure firms make a trade-off between costs of adjustment and benefits associated with adjustment to a new capital structure policy. According to Uysal (2011), there exists a correlation between financing and investment decisions. In such case, the best optimal strategy for a firm will not be to return immediately to a target level of capital structure depending on the nature of investing decisions. Hovakimian and Li (2009) suggested an ex post and ante comparison of capital structure with respect to transaction costs to find out that firms do not have unique debt ratios; instead, firms follow a target capital structure and firms rebalance to an optimal capital structure depending upon the adjustment costs associated with capital structure.

Rajan and Zingales (1995) while analyzing capital structure choices at G7 countries found that there exists a similar correlation between the capital structure and the determinants across different countries. Fan et al. (2008) conducted a thorough analysis of capital structure of 39 countries. They found that countries having weak shareholders protection exhibit a strong correlation between leverage and profitability. For developed capital markets like USA, there exist a strong positive relationship of leverage with size, tangibility, inflation, and industry median. Equity is positively related to positive shocks in profitability and negatively correlated with debt. As argued in literature, firms do not immediately adjust to optimal capital structure policy due to transaction costs so there is a negative correlation between profitability and leverage. Ang et al. (1997) analyzed capital structure in Indonesian firms. They found that that trade-off theory has a very weak support in the Indonesian market, and thus, firms operate as there is no optimal leverage level. They found that leverage is influenced by non-debt tax shield, firm liquidity, and information about a firm's share price.

Another alternative model with respect to trade-off theory is the pecking order theory. The pioneers of pecking order theory included the studies of Donaldson (1961), Myers (1984), and Myers and Majluf (1984). Pecking order theory suggests that firms financing choices follow a path defined by a firm's preferences. Firms prefer internal financing over external financing, and debt is normally preferred over equity. Thus, firms do not possess a strategy of a target capital structure. Myers (1984) further argues that there exists information asymmetry between managers and shareholders which 
results in costs of adverse selection. These factors compel firms to follow a pecking order in their financing. Financing through debt may increase the financial distress risk. Because of this, firms follow a preference strategy by first relying on internal funds. In the absence of any internal funds, firms then issue the safest securities which imply that firms should issue debt in the absence of internal funds. Halov and Heider (2006) argued that adverse selection is a major problem for small firms because large firms have less costs in time of adverse selection by considering the possibility of a risky or mispriced value of debt. Hovakimian et al. (2001) argued that firms follow the pecking order theory and they found empirical results where firms used to finance short-term investment through a pecking order model. This implies that firms prefer internal funds to finance small projects. Welch (2007) found that to finance bigger projects, firms usually use external funds by first going for the cheapest debt.

The examples of testing pecking order model in developed nations include studies conducted by Bessler et al. (2008) and Welch (2004). As far as Asia is concerned, it shows a mixed reaction regarding trade-off and pecking order models. While analyzing firms in Thailand, Wiwattanakantang (1999) found that financing decisions in Thai firms are shaped by tax shields effects, signaling mechanism, and agency conflicts thus showing a tendency towards a pecking order. Fattouh et al. (2005) found enormous nonlinear relationship between capital structure and its determinants while analyzing Korean firms over a period from 1992 to 2001. This nonlinearity accounts for the presence of information asymmetry. Colombage (2005) reported findings in support of pecking order model while analyzing Sri Lankan firms. On the other hand, there are studies which report findings contrary to pecking order theory. These include study conducted by Yau et al. (2008) in Malaysian market. They found a negative relationship between long-term debt and a firm's financing requirements. Thus, contemporary studies on capital structure decisions of a firm in Asian markets have no clear picture. This fact motivates us to conduct a study on capital structure decisions and adjustment behavior of Chinese firms with respect to their leverage.

\section{Target adjustment hypothesis}

Getzmann et al. (2014) argue that there are three important questions related to the adjustment of firms to an optimal level of capital structure. First, how much time a firm takes to adjust to its target level? What is the cost of adjustment and how firms respond to capital structure shocks? These questions are beyond the scope of a traditional static trade-off model and thus come under the dynamic target adjustment hypothesis (Frank and Goyal 2008). Flannery and Hankins (2007) argue that the speed with which a firm adjusts to its target capital depends on the cost of adjustment and costs associated with deviations from a target capital structure. Adjustment costs depend on transaction costs, and market value of firms' equity. Flannery and Hankins (2007) further argue that cost of deviating from a target capital structure depends on chances of financial distress and tax shield associated with deviating policy. Faulkender and Wang (2006) further reported that adjustment speed of firms with volatile or negative cash flows is significantly different from firms with free cash flows.

Many researchers attempted to find out the adjustment speed to an optimal level of leverage, and there exists greater variations in their findings, i.e., 34\% (Flannery and 
Rangan 2006), $13 \%$ in LS regressions and $25 \%$ in generalized method of moments (GMM) regressions (Lemmon et al. 2008), 17\% (Huang and Ritter 2009), and 15\% (Frank and Goyal 2008).

\section{Institutional environment in China and capital structure}

To safeguard the overall market competitiveness in the context of recent swift development in Chinese economy, firms try to adjust their leverage with respect to different internal and external factors (Duan et al. 2012).The internal and external factor coupled with macroeconomic factors have profound effect on the pace with which firms adjust to an optimal leverage policy (Cook and Tang 2010 ). Duan et al. (2012) empirically found that certain factors like state ownership, non-state economic structure, and the extent of state intervention in different enterprises combined with legal and commercial landscape have important implications for firms' adjustment towards an optimal capital structure policy.

Chinese market has incorporated numerous reforms and has been considerably restructured over the last 30 years. This has led to an increase in the number of listed companies. However, the state-owned and non-state-owned enterprises differ in the nature of their ownership, agency relationships, and bankruptcy costs and associated risks. One important reform in this regard is the corporatization of previously owned state-owned enterprises. After corporatization, the government still holds the status of the majority shareholder and has two important rights: appointment of key organization posts like chief executive officer and the government has the optimal right of decisions of assets disposals and merger and acquisitions (Qian 1995). In the light of this fact of state involvement in asset disposal and mergers and acquisitions, stateowned enterprises may have low bankruptcy risk and they can get bailout packages from the government in time of financial distress (Faccio et al. 2006). The government, in effect, serves as an insurance provider for SOEs. Another important implication with respect to the appointment of CEO by the state is that the CEO thus appointed may have some divergent goals. Their promotion and compensation are measured by various political and social objectives.

Moreover, SOEs and NSOEs have a differential access to bank loans which is the predominant financing alternative in Chinese market. SOEs are advanced abundant of loans because of political, employment, and tax reasons other than profitability (Brandt and Li 2003). In contrast, banks' loan-granting decisions to NSOEs are based largely on financial rather than on political considerations. The institutional environment with respect to SOEs and NSOEs has important implications for the adjustment speed of these firms towards an optimal leverage policy.

As for as state-owned enterprises in China are concerned, they are expected to adjust to a target level of capital structure; however, the political pecking order of loans towards SOEs may increases the speed of adjustment towards a target leverage policy in SOEs. Thus, SOEs are expected to report a higher adjustment rate as compared to NSOEs.

On the basis of above discussion the following two hypotheses are formulated.

H1: Chinese firms show adjustment towards a target leverage policy.

$\mathrm{H} 2$ : The adjustment towards leverage policy is higher in Chinese SOEs than that in Chinese NSOEs. 


\section{Determinants of capital structure}

This study analyzes the determinants of capital structure at three levels, i.e., firmlevel, industry-level, and country-level determinants. Explanation of each level of determinants is given as follows.

\section{Firm-level determinants of capital structure}

Growth opportunities This study employs market to book ratio to measure growth opportunities. Jensen (1986) argues that if firms possess high growth opportunities, they can mitigate the agency costs associated with free cash flow thus reducing their dependence on debt. In this way, the disciplinary role of debt can be reduced. Due to higher growth opportunities, firms may invest in innovative and riskier projects that will increase their cost of debt, and thus, investment in risky projects may lead to an asset substitution problem. Thus, firms are more attracted to internal financing or equity financing in case of high growth opportunities. Debt servicing associated with debt financing may warrant additional risk that makes debt more vulnerable. Thus, a lower leverage is expected for firms having high market to book ratio. This negative relationship is further confirmed by Wiwattanakantang (1999) and Kayo and Kimura (2011) who based their discussion on trade-off and agency cost theories. On the other hand, Chen (2004) found a positive relationship between growth opportunities and leverage for Chinese firms. Thus, the relationship between leverage and growth opportunities is unclear and it can be both ways.

H3: Growth opportunities significantly affect leverage policy in Chinese firms.

Profitability Profitability is measured through the ratio of earnings before interest and taxes to total assets. Pecking order theory of capital structure suggests that due to information asymmetry between managers and outside investors, retained earnings are preferred by managers to finance their projects. Moreover, in times of high profitability, firms may tend to retain their earnings rather than investing in risky securities. Potential dilution of ownership associated with equity financing may also compel managers not to raise equity. Titman and Wessels (1988) reported a negative relationship between profitability and leverage. Bevan and Danbolt (2002) while analyzing firms in UK also found a negative relationship between firm leverage and profitability. Their findings are consistent with pecking order theory of capital structure. Chakraborty (2010) also found negative and statistically significant relationship between leverage and profitability in Indian firms.

Bowen et al. (1982) found a positive relationship between leverage and profitability. Their findings were based on trade-off and agency theories of capital structure.

Thus, the relationship is not clear. According to pecking order theory, there exist a negative relationship between leverage and profitability. On the other hand, trade-off and agency cost theories advocate a negative relationship between leverage and profitability.

H5: There is a significant relationship between profitability and leverage in Chinese firms.

Size This study takes natural log of assets as proxy for size of the firm. Trade off theory of capital structure advocates that firm size and its leverage are positively related. Firms having larger size are more differentiated which make them less vulnerable to 
bankruptcy as compared to low-sized firms. Additionally, larger firms issue more information and thus, larger firms exhibit lower monitoring costs consequently reducing the agency cost associated with debt for larger firms. Furthermore, larger firms have better access to markets, stable cash flows and take benefits from the tax shield associated with debt financing. Deesomsak et al. (2004) while analyzing capital structure across a cross-section of countries found a positive relationship between leverage and size of the firm except for Singapore. Their arguments were based on trade-off theory of capital structure. Hence, leverage is expected to show positive relationship with firm size. In accordance with agency theory, Kayo and Kimura (2011) reported the same empirical findings based on the agency theory. Chakraborty (2010) and Muradoglu and Sivaprasad (2011) found a negative relationship for leverage and size of firm. They reported their findings based upon pecking order theory of capital structure. Thus, relationship between leverage and size is an ambiguous one and thus, it can be both positive and negative.

H6: Size and leverage are significantly related in Chinese firms.

Ownership concentration Degree of ownership concentration is measured through shares held by the five largest shareholders of the firm. Agency cost associated with ownership can be mitigated through high ownership concentration since concentrated ownership results in higher level of monitoring by large shareholders (Wiwattanakantang 1999). According to Pound and Zeckhauser (1990), existence of active monitoring in the presence of large shareholders reduces the chances of asset substitution problem. Thus, ownership concentration is expected to negatively affect firm leverage. Pandey (2001) and King and Santor (2008) advocates a negative relationship between ownership concentration and leverage.

H7: There is a negative relationship between ownership concentration and leverage in Chinese firms.

Non-debt tax shield (NDTS) Non-debt tax shield is measured through the ratio of depreciation to total assets. Potential tax benefits associated with debt financing are reduced by non-debt tax shields. Thus, the expected relationship between NDTS and leverage is negative. Chang and Rhee (1990) and Chakraborty (2010) reported a positive relationship between non-debt tax shield and leverage. However, Miguel and Pindado (2001) and Deesomsak et al. (2004) advocate a negative relationship between non-debt tax shield and leverage of a firm. They base their findings on trade-off theory that firm makes a trade-off between the benefits of NDTS and financial distress risk.

H8: Non-debt tax shield significantly affects firms' leverage in China.

Firms' asset liquidity This study uses networking capital as a proxy for firms' liquidity. Based on the trade-off theory, Alves and Ferreira (2011) suggest that firm asset liquidity is positively correlated with leverage. However, Deesomsak et al. (2004) suggest a negative relationship. Their arguments are based on pecking order theory. Moreover, they argue that managers may change liquid assets to give preference to shareholders instead of debt holders and thereby increasing the associated agency costs. This implies a negative relationship between assets' liquidity and leverage. Thus, the relationship 
between leverage and a firm's asset liquidity is an unclear one and it can be positive as well as negative.

H9: There is a significant relationship between firm's asset liquidity and firm leverage in Chinese firms.

Tax to earning ratio Scott (1976) after comprehensive comparative statistical analysis found that optimal debt level is an increasing function of corporate tax rate. A significant reason for firms' preference of debt over equity is tax shield attained through interest payments (Modigliani and Miller 1963). So firms with high corporate tax rate are expected to raise more debt than firms with lower corporate tax rate.

On the other hand, Sogorb-Mira (2005) reports a negative relationship between leverage and corporate tax and argues that this negative relationship may be due to the reverse causation between taxes and firm leverage. Korajczyk and Levy (2003) also report a negative relationship and argue that firms have lower target leverage if they have large tax shields. Their arguments are based on trade-off theory of capital structure. Thus, the relationship between leverage and corporate taxes is an unclear one and can be both positive as well as negative.

H10: Corporate tax ratio significantly affects firm leverage in Chinese firms.

\section{Industry-level determinants}

Industry leverage is expected to positively affect a firm's policy of issuing debts, and thus, a positive and statistically significant relationship is expected between firm leverage and industry leverage. However, industry liquidity is a sign of good prospect of internal funds for the whole industry and thus, it is expected to negatively affect firms' leverage.

MacKay and Phillips (2005) report higher leverage for firms which constitute a concentrated industry. They also found a stronger strategic interaction between leverage and industry concentration. One explanation might be that highly concentrated industries have firms that are powerful, and some might enjoy monopolistic status that increases their chances of raising debts most frequently and in larger amounts.

On the other hand Kayo and Kimura (2011) found a negative relationship between leverage and industry concentration. They found this relationship while analyzing firms from emerging markets. This relationship can be due to different characteristics of industries based on industry concentration. Firms in highly concentrated industries have higher size and profitability and have usually higher risk profile (MacKay and Phillips 2005). This higher risk can be related to the incentives provided to equity holders in case of high bankruptcy chances due to higher risk. This accounts for the negative relationship between industry concentration and leverage of the firm. Hence, the relationship between leverage and industry concentration is an ambiguous one and it can be both positive and negative.

H11: Industry leverage positively affects firm leverage in China.

H12: There is a negative relationship between industry liquidity and firm leverage in China.

H13: Industry concentration significantly affects firm leverage in Chinese firms.

\section{Country-level determinants}

Gross domestic product

De Jong et al. (2008) suggested a positive relationship between capital structure and GDP. They argue that countries having better legal environment and having healthier 
growth rate are likely to take more debt. They further argue that macroeconomic indicator like GDP not only significantly affects capital structure of a firm but also influences the firm-specific factors affecting capital structure. Bond market is highly developed in richer nations, and firms have easy access to prevalent loans in the market, and thus, firms raise more capital through debt because of access and ease of getting loans.

However, Cheng and Shiu (2007) found a negative relationship between leverage and GDP. They suggest that richer countries having high GDP growth rate report less leverage than poor countries having a sluggish GDP growth rate. Kayo and Kimura (2011) found a negative relationship as well and argued that firm-specific factors are more significant in affecting capital structure than country-level factors. Thus, relationship between leverage and GDP is unclear and it can be inferred that GDP significantly affects leverage of a firm.

H14: There is a significant relationship between a country's GDP and a firm's leverage.

\section{Inflation rate}

Inflation has a significant influence on capital structure choices. Taggart (1985) argue that inflation enhances the influence of tax advantage on capital structure. This combined interaction between inflation and tax is a better explanation of capital structure patterns, and thus, inflation has a greater influence on leverage policy than tax alone. They further argue that influence of inflation is also depicted in considering the real GNP price deflator. High inflation rate interacts with high tax shield incentives and thereby increases the corporate debt financing ratios.

On the other hand, Cheng and Shiu (2007) argue that indirect influence of inflation on leverage policy is unclear. They highlight the work of Fisher who predicted the relationship between forecasted inflation rate and unadjusted interest rates. Cheng and Shiu (2007) argue that high inflation rate may increase debt cost on the one hand; however, with increasing inflation rate, firms tend to increase their debt financing by exploiting the residuals they get from inflated assets and fixed liabilities. Based on these arguments, it becomes clear that inflation affects leverage policy of a firm significantly; however, the relationship is unclear and can be both positive and negative.

H15: Inflation rate has a significant effect on firms' leverage in China.

\section{Lending rate}

Muradoglu and Sivaprasad (2011) empirically found that leverage and lending rate are negatively related. This study uses the data of World Bank Databank for lending rate.

H16: Lending rate negatively affects firms' leverage in China.

\section{Methods}

\section{Data and data sources}

The study uses a rich data set of 760 A-listed firms, listed on Shanghai and Shenzan Stock exchanges. Data span is from 2001 to 2012. Data is collected from RESET Chinese database. Data belongs to nonfinancial firms. All financial and regulatory firms are excluded from analysis. The codes for company ranges from C00002 to C600898. Firms having at least 7 years of data are included in the analysis. The data is then categorized into state-owned and non-state-owned enterprises. Analyses are done for overall date and subsamples of SOEs and NSOEs. 


\section{Model specification}

Flannery and Rangan (2006) argue that when there are no market frictions firms maintain a target level of leverage. In this context, we developed a static model based on our variables. The static model is given as follows:

$$
\begin{aligned}
\mathrm{LEV}_{i t} & =\beta_{0}++\beta_{1} \mathrm{PROF}_{i t}+\beta_{2} \mathrm{SIZE}_{i t}+\beta_{3} \mathrm{NWC}_{i t}+\beta_{4} \mathrm{OC} \%+\beta_{5} \mathrm{NDTS}_{i t}+\beta_{6} \mathrm{BSIZE}_{i t} \\
& +\beta_{7} \mathrm{MTB}_{i t}+\beta_{8} \mathrm{TR}_{i t}+\beta_{9} \mathrm{INDLEV}_{i t}+\beta_{10} \mathrm{INDLIQ}_{i t}+\beta_{11} \mathrm{INDHHI}_{i t} \beta_{12} \mathrm{GDP}_{t} \\
& +\beta_{12} \mathrm{INF}_{t}+\beta_{14} \mathrm{LR}_{t}+e_{i t}
\end{aligned}
$$

In Eq. 1,

$\mathrm{LEV}_{i t}$ is the leverage of a firm $i$ at time $t$. It is measured through the ratio of debt and assets.

$\mathrm{PROF}_{i t}$ is the profitability of a firm $i$ at time $t$.

$\mathrm{SIZE}_{i t}$ is the size of a firm $i$ at time $t$.

$\mathrm{NWC}_{i t}$ is the networking capital of a firm $i$ at time $t$. It is used as a proxy for firm liquidity.

OC5 $\%_{i t}$ is the ownership dispersion at $5 \%$ of a firm $i$ at time $t$.

NDTS $_{i t}$ is the non-debt tax shield of a firm $i$ at time $t$.

BSIZE $_{i t}$ is the board size of a firm $i$ at time $t$.

$\mathrm{MTB}_{i t}$ is the market to book ratio of a firm $i$ at time $t$. It is used as a proxy for measuring growth opportunities.

$\mathrm{TR}_{i t}$ is the tax to earnings ratio of a firm $i$ and at time $t$.

INDLEV $_{i t}$ is the industry leverage of an industry $i$ at time $t$.

$\mathrm{INDLIQ}_{i t}$ is the industry liquidity of a an industry $i$ at time $t$.

$\mathrm{NDHHI}_{i t}$ is the industry concentration of an industry at time $t$. It is measured by using Heirschman Herfindhal Index.

$G D P_{i t}$ is the gross domestic product of China at time $t$.

INF is the inflation rate of China at time $t$.

$\mathrm{LR}_{t}$ is the lending rate in China at time $t$.

Two important implications related to static model of Eq. 1 are the problem of endogeneity (Adrian and Boyarchenko 2015 and Juselius and Drehmann 2015) and cost associated with adjustment to a target level of leverage. Endogeneity can be prevented by introducing proper instruments. On the other hand, a firm cannot immediately adjust to its target level of capital structure due to associated costs. In this context, the relationship between current and target leverage can be expressed through the following equation.

$$
\mathrm{LEV}_{i t}-\mathrm{LEV}_{i t-1}=\gamma\left(\mathrm{LEV}_{i t}-\mathrm{LEV}^{*}{ }_{i t-1}\right)
$$

In Eq. 2, $\left(\mathrm{LEV}_{i t}-\mathrm{LEV}^{*}{ }_{i t-1}\right)$ shows the adjustment required by a firm to adjust to a target level. $\gamma$ is the coefficient of adjustment. A value of this coefficient ranges from 0 to 1 . If $\gamma$ is equal to zero, then $\mathrm{LEV}_{i t}=\mathrm{LEV}_{t-1}$. This implies that a firm does not try to achieve an optimal level of leverage due to the associated costs and wants to remain with its current policy. However, if $\gamma$ is equal to 1 , then $\operatorname{LEV}_{i t}=\mathrm{LEV}_{i t}^{*}$. In this case, a firm wants to achieve a target level of leverage. 
By putting Eq. 1 into Eq. 2, we get the following equation.

$$
\begin{aligned}
\mathrm{LEV}_{i t} & =\gamma \beta_{0}+(1-\gamma) \mathrm{LEV}_{i t-1}+\gamma \beta_{1} \mathrm{PROF}_{i t}+\gamma \beta_{2} \mathrm{SIZE}_{i t}+\gamma \beta_{3} \mathrm{NWC}_{i t}+\gamma \beta_{4} \mathrm{OC}_{5} \%+\gamma \beta_{5} \mathrm{NDTS}_{i t} \\
& +\gamma \beta_{6} \mathrm{BSIZE}_{i t}+\gamma \beta_{7} \mathrm{MTB}_{i t}+\gamma \beta_{8} \mathrm{TR}_{i t}+\gamma \beta_{9} \mathrm{INDLEV}_{i t} \\
& +\gamma \beta_{10} I N D L I Q_{i t}+\gamma \beta_{11} \mathrm{INDHHI}_{i t}+\gamma \beta_{12} \mathrm{GDP}_{t}+\gamma \beta_{13} \mathrm{INF}_{t}+\gamma \beta_{14} \mathrm{LR}_{t}+\eta_{i}+\lambda_{t}+\gamma e_{i t}
\end{aligned}
$$

$\eta_{i}$ in Eq. 3 corresponds to firm-specific effects while $\lambda_{t}$ are the time-specific effects. Simplifying Eq. 3, the following equation results.

$$
\begin{aligned}
L E V_{i t} & =\gamma \beta_{0}+\rho \mathrm{LEV}_{i t-1}+\delta_{1} \mathrm{PROF}_{i t}+\delta_{2} \mathrm{SIZE}_{i t}+\delta_{3} \mathrm{NWC}_{i t}+\delta_{4} \mathrm{OC}_{i t}+\delta_{5} \mathrm{NDTS}_{i t} \\
& +\delta_{6} \mathrm{BSIZE}_{i t}+\delta_{7} \mathrm{MTB}_{i t}+\delta_{8} \mathrm{TR}_{i t}+\delta_{9} \mathrm{INDLEV}_{i t} \\
& +\delta_{10} \mathrm{INDLIQ}_{i t}+\delta_{11} \mathrm{INDHHI}_{i t}+\delta_{12} \mathrm{GDP}_{t}+\delta_{13} \mathrm{INF}_{t}+\delta_{14} \mathrm{LR}_{t}+\eta_{i}+\lambda_{t}+v_{i t}
\end{aligned}
$$

In Eq. $4, \alpha=\gamma \beta_{0}, \rho=(1-\gamma), \delta_{k}=\gamma \beta_{k}$, and $\lambda_{t} v_{i t}=\gamma e_{i t}$

Due to problem of endogeneity and firms' option for a target level of leverage, OLS is inconsistent to estimate Eq. 4. To cope with these issues, this study uses two-step generalized method of moments (GMM) following Rehman and Wang (2015). The study uses GMM's method of Arellano and Bover (1995)/Blundell and Bond (2000) to estimate Eq. 4. To estimate the static model of Eq. 1, the study uses OLS technique and fixed-effects models with an added AR term to account for serial correlation. These estimation methods were more recently used in research studies of Getzmann et al. (2014) and Rehman and Wang (2015).

\section{Description of the sample}

Table 1 shows descriptive statistics of the sample. A total of 760 firms over a period from 2001 to 2013 are selected for analyses. Firms having at least 7 years of data are selected for analysis in order to avoid the issues of survivorship bias. Firms are then categorized into state-owned enterprises and non-state-owned enterprises.

\section{Estimation strategy}

A total of four models are used to estimate Eqs. 1 and 4. In order to estimate the static model of Eq. 1, we used pooled OLS and GLS fixed-effect estimation. However, due to the inconsistency of OLS to estimate Eq. 4, the study uses generalized method of moments. For this purpose, two methods are adopted. The study uses GMM's method of Arellano and Bover (1995)/Blundell and Bond (2000) to estimate Eq. 4. Two-step GMM is used in order to get robust and consistent estimation. Columns 1 and 2 of Tables 3, 4, and 5 represent the coefficient of static model 1 for overall firms, stateowned enterprises, and non-state-owned enterprises, respectively. While columns 3 and 4 show coefficients for Blundell and Bond (2000) and Arellano and Bover (1995), respectively.

Table 2 shows the correlation between different variables. VIF is the variance inflation factor. Correlation coefficients and VIF are well in accepted range, and there is no serious issue of correlation between independent variables and error term. 
Table 1 Descriptive statistics

\begin{tabular}{|c|c|c|c|c|c|c|c|c|c|}
\hline \multirow[t]{2}{*}{ Variables } & \multicolumn{3}{|c|}{ Overall firms } & \multicolumn{3}{|l|}{ SOES } & \multicolumn{3}{|c|}{ NSOES } \\
\hline & Obs & Mean & d. dev. & Obs & Mean & Std. dev. & $\overline{O b s}$ & Mean & Std. dev. \\
\hline EV & 9728 & 0.573245 & 0.241387 & 4677 & 0.714205 & 0.134716 & 5061 & 0.64035 & 0.102187 \\
\hline PROF & 9728 & 0.026066 & 0.258414 & 4677 & 0.020109 & 0.351002 & 5061 & 0.031582 & 0.12034 \\
\hline ZE & 9728 & 21.44831 & 259129 & 4677 & 21.44514 & 1.284653 & 5061 & 21.45124 & \\
\hline WC & 9728 & 0.16854 & 0.187912 & 4677 & 0.167508 & 0.181677 & 5061 & 0.169496 & 0.193519 \\
\hline C5\% & 9262 & 1.18352 & 1.20283 & 4474 & 1.211944 & 1.250436 & 4788 & 1.156961 & 1.156075 \\
\hline NDTS & 9342 & 0.026311 & 0.019057 & 4515 & 0.026319 & 0.019601 & 4827 & 0.026303 & 0.018536 \\
\hline IZE & 2 & 1 & 4.56154 & 4286 & 12.06463 & 4.600621 & 4626 & 11.82101 & 4.522 \\
\hline MTB & 9195 & 1.955092 & 0.983543 & 4392 & 1.970821 & 0.989267 & 4803 & 1.940708 & 0.978161 \\
\hline$T R$ & 9712 & 0.19621 & 1.151021 & 4670 & 0.189865 & 0.703934 & 5042 & 0.202086 & 1.446778 \\
\hline JDLEV & 9729 & 0 & 0.8 & 46 & 0.58769 & 7 & 5062 & 0.58818 & 8 \\
\hline IDLIQ & 9729 & 0.279566 & 0.116911 & 4677 & 0.278149 & 0.116506 & 5062 & 0.280877 & 0.117282 \\
\hline $\mathrm{NDHHI}$ & 9697 & 6.616584 & 0.677652 & 4661 & 6.621999 & 0.6880 & 5036 & 6.611572 & 0.667 \\
\hline GDP & 9729 & 10.02401 & 1.737035 & 4677 & 10.0241 & 1.73844 & 5062 & 10.02393 & 1.735906 \\
\hline IFL & 9729 & 2.301725 & 2.138121 & 4677 & 2.302562 & 2.139277 & 5062 & 095 & 2.137261 \\
\hline$L R$ & 9729 & 5.84974 & 0.591671 & 4677 & 5.849925 & 0.592364 & 5062 & 5.849568 & 0.591087 \\
\hline
\end{tabular}

LEV is the leverage measured through the ratio of debt to asset. PROF is the profitability measured through the ratio of return on equity. SIZE is the firm's size measured through natural log of a firm's asset. NWC is the networking capital used as a proxy for a firm's liquidity. NWC is measured by subtracting accounts payable from the sum of accounts receivables and inventory. The value is then scaled by total assets. OC5\% is ownership concentration. NDTS is the non-debt tax shield measured through the proportion of sum of amortization and depreciation to total assets. BSIZE is the board size measured through number of directors on a firm's board of directors. MTB is the market to book ratio used as a proxy for growth oppurtunities.TR is the tax to earnings ratio used a proxy for corporate tax rate, and it is measured as proportion of taxes to earnings before taxes. INDLEV is the median industry leverage as median of total debt to total asset ratios of involved companies in an industry. INDLIQ is the industry liquidity. INDHHI is Herfindahl-Hirschman Index (HHI) as the sum of the squares of a firm's sales to an industry's total sales. GDP is the real annual gross domestic product. INFL is the inflation rate in China. LR is the lending rate in China

\section{Results and Discussion}

\section{Adjustment speed}

Columns 3 and 4 of Tables 3, 4, and 5 correspond to dynamic model estimation of Eq. 4. Table 3 indicates coefficients for overall firms. One of the significant results in Tables 3, 4, and 5 is the lagged leverage variable. The value of LEV(L1) for overall, SOEs, and NSOEs is positive and is statistically significant. These results correspond to the findings of Ur Rehman et al. (2016). Ur Rehman et al. (2016) empirically found that Chinese firms follow a target level of leverage using generalized method of moments for their estimation. This infers that Chinese firms show behavior towards a target level of leverage. The coefficient of $\operatorname{LEV}(1)$ is positive and significant for both GMM1 and GMM2. The adjustment coefficient for overall firms with respect to GMM1 (Arellano and Bover 1995 ) is 0.325, and with respect to GMM2, (Blundell and Bond 2000) it is 0.30. Adjustment coefficient is calculated by subtracting the coefficients of GMM estimates from 1. These two findings of GMM1 and GMM2 have no significant difference. This adds robustness to our findings. It implies that Chinese firms take 3 years (approximately) to adjust their leverage policy.

Columns 3 and 4 of Table 4 correspond to dynamic model estimation of Eq. 4 for state-owned enterprises. GMM1 reports an adjustment coefficient of 0.3912(1-0.6088) while GMM2 reports a coefficient of $0.4749(1-0.526)$ for state-owned enterprises. 


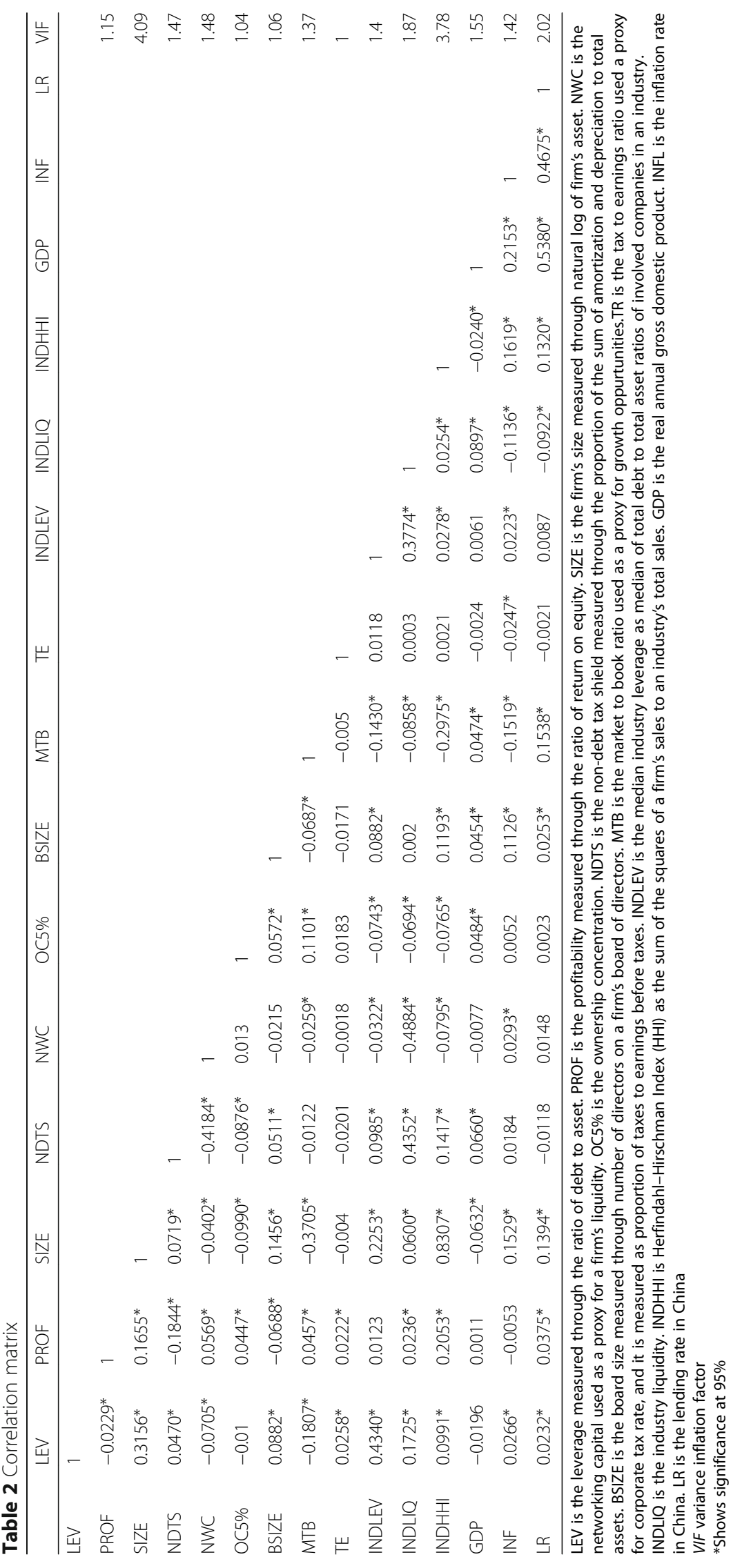


Table 3 Regression output for overall firms

\begin{tabular}{|c|c|c|c|c|}
\hline & OLS & GLS fixed-effects & GMM1 & GMM2 \\
\hline \multirow[t]{2}{*}{ LEV(L1) } & & & $0.675^{* * *}$ & $0.70^{* * *}$ \\
\hline & & & -0.0204 & -0.0335 \\
\hline \multirow[t]{2}{*}{ PROF } & $-0.0331^{* * *}$ & $-0.023^{* * *}$ & $-0.048^{* *}$ & $-0.05^{* *}$ \\
\hline & -0.0094 & -0.0086 & -0.0192 & -0.0203 \\
\hline \multirow[t]{2}{*}{ SIZE } & $0.0434^{* * *}$ & $0.0453^{* * *}$ & $0.026^{* * *}$ & $0.02^{* * *}$ \\
\hline & -0.0016 & -0.0022 & -0.0044 & -0.0048 \\
\hline \multirow[t]{2}{*}{ NWC } & $-0.0402^{* * *}$ & $-0.0246^{* *}$ & 0.0029 & 0.0038 \\
\hline & -0.0065 & -0.0079 & -0.0165 & -0.017 \\
\hline \multirow[t]{2}{*}{ OC5\% } & $-0.0036^{* * *}$ & $-0.0012^{* *}$ & -0.0024 & -0.0024 \\
\hline & -0.0008 & -0.0009 & -0.0014 & -0.0015 \\
\hline \multirow[t]{2}{*}{ NDTS } & -0.0066 & -0.1055 & $-0.2677^{* *}$ & $-0.27^{* *}$ \\
\hline & -0.0584 & -0.0733 & -0.1539 & -0.1705 \\
\hline \multirow[t]{2}{*}{ BSIZE } & $0.0004^{*}$ & $0.0008^{* *}$ & 0.0003 & 0.0005 \\
\hline & -0.0002 & -0.0003 & -0.0003 & -0.0003 \\
\hline \multirow[t]{2}{*}{ MTB } & $0.0059^{* * *}$ & 0.0017 & $0.0036^{* *}$ & $0.0025^{*}$ \\
\hline & -0.0012 & -0.0011 & -0.0014 & -0.0015 \\
\hline \multirow[t]{2}{*}{ TR } & $0.0019^{* *}$ & $0.0015^{* *}$ & 0.0001 & 0.0001 \\
\hline & -0.0007 & -0.0006 & -0.0006 & -0.0006 \\
\hline \multirow[t]{2}{*}{ INDLEV } & $0.6364^{* * *}$ & $0.5375^{* * *}$ & $0.365^{* * *}$ & $0.37^{* * *}$ \\
\hline & -0.0222 & -0.0295 & -0.0631 & -0.0657 \\
\hline \multirow[t]{2}{*}{ LNDLIQ } & -0.0048 & $-0.0508^{*}$ & -0.0454 & -0.0284 \\
\hline & -0.0103 & -0.0202 & -0.0325 & -0.0347 \\
\hline \multirow[t]{2}{*}{ INDHHI } & $-0.0540^{* * *}$ & $-0.0394^{* *}$ & $-0.018^{* *}$ & $-0.01^{* *}$ \\
\hline & -0.0027 & -0.0037 & -0.0061 & -0.0064 \\
\hline \multirow[t]{2}{*}{ GDP } & 0.0003 & $0.0022^{* * *}$ & $0.003^{* * *}$ & $0.003^{* * *}$ \\
\hline & -0.0007 & -0.0006 & -0.0007 & -0.0007 \\
\hline \multirow[t]{2}{*}{ INFL } & -0.0008 & $-0.0008^{* *}$ & -0.0001 & -0.0001 \\
\hline & -0.0005 & -0.0004 & -0.0004 & -0.0004 \\
\hline \multirow[t]{2}{*}{ LR } & -0.0019 & $-0.006^{* * *}$ & $-0.009^{* * *}$ & $-0.009^{* * *}$ \\
\hline & -0.0021 & -0.0018 & -0.002 & -0.0021 \\
\hline Constant & -0.5308 & -0.6217 & -0.4935 & -0.49 \\
\hline Adj $R$ & 0.3015 & 0.2608 & & \\
\hline F Stat & 120.73 & 94.62 & & \\
\hline Abond test & & & 0.7901 & \\
\hline Wald $c h i^{2}$ & & & $2092.9^{* *}$ & $593.0^{* * *}$ \\
\hline Sargan test & & & 0.531 & 0.375 \\
\hline Hausman test & & $47^{* * *}$ & & \\
\hline
\end{tabular}

Standard errors are given in parentheses

$*, * * * *$ Show significance at 90,95 , and $99 \%$, respectively

LEV is the leverage measured through the ratio of debt to asset. PROF is the profitability measured through the ratio of return on equity. SIZE is the firm's size measured through natural log of firm's asset. NWC is the networking capital used as a proxy for a firm's liquidity. OC5\% is the ownership concentration. NDTS is thenon-debt tax shield measured through the proportion of the sum of amortization and depreciation to total assets. BSIZE is the board size measured through number of directors on a firm's board of directors. MTB is the market to book ratio used as a proxy for growth oppurtunities. TR is the tax to earnings ratio used a proxy for corporate tax rate, and it is measured as proportion of taxes to earnings before taxes. INDLEV is the median industry leverage as median of total debt to total asset ratios of involved companies in an industry. INDLIQ is the industry liquidity. INDHHI is Herfindahl-Hirschman Index (HHI) as the sum of the squares of a firm's sales to an industry's total sales. GDP is the real annual gross domestic product. INFL is the inflation rate in China. LR is the lending rate in China 
Table 4 Regression output for state-owned enterprises

\begin{tabular}{|c|c|c|c|c|}
\hline & OLS & GLS fixed-effects & GMM1 & GMM2 \\
\hline \multirow[t]{2}{*}{ LEV(L1) } & & & $0.6088^{* * *}$ & $0.526^{* * *}$ \\
\hline & & & -0.0332 & -0.0581 \\
\hline \multirow[t]{2}{*}{ PROF } & $-0.0214^{*}$ & -0.0137 & $-0.0471^{* *}$ & $-0.044^{* *}$ \\
\hline & -0.0116 & -0.0114 & -0.0194 & -0.0187 \\
\hline \multirow[t]{2}{*}{ SIZE } & $0.0459^{* * *}$ & $0.0510^{* * *}$ & $0.0374^{* * *}$ & $0.032^{* * *}$ \\
\hline & -0.0022 & -0.0033 & -0.0074 & -0.0075 \\
\hline \multirow[t]{2}{*}{ NWC } & $-0.0289^{* *}$ & -0.0052 & -0.0348 & -0.0222 \\
\hline & -0.0092 & -0.0118 & -0.0214 & -0.0208 \\
\hline \multirow[t]{2}{*}{ OC5\% } & $-0.0027^{* *}$ & -0.0006 & -0.0019 & -0.002 \\
\hline & -0.0011 & -0.0014 & -0.0016 & -0.0015 \\
\hline \multirow[t]{2}{*}{ NDTS } & -0.0003 & -0.0007 & $-0.0708^{*}$ & $-0.1124^{*}$ \\
\hline & -0.0003 & -0.0004 & -0.2026 & -0.2127 \\
\hline \multirow[t]{2}{*}{ BSIZE } & -0.0057 & $-0.0023^{*}$ & -0.0001 & -0.0002 \\
\hline & -0.0016 & -0.0017 & -0.0004 & -0.0004 \\
\hline \multirow[t]{2}{*}{ MTB } & $0.0063^{* *}$ & 0.0063 & 0.0014 & 0.0008 \\
\hline & -0.0017 & -0.0015 & -0.0018 & -0.0017 \\
\hline \multirow[t]{2}{*}{ TR } & $0.0006^{* * *}$ & $0.006^{* * *}$ & 0.0007 & 0.0008 \\
\hline & -0.032 & -0.0451 & -0.0005 & -0.0005 \\
\hline \multirow[t]{2}{*}{ INDLEV } & $0.62^{* * *}$ & $0.547^{* * *}$ & $0.2207^{* *}$ & $0.2634^{* *}$ \\
\hline & -0.0144 & -0.0302 & -0.088 & -0.0875 \\
\hline \multirow[t]{2}{*}{ LNDLIQ } & -0.119 & -0.0243 & -0.053 & -0.0321 \\
\hline & -0.0808 & -0.106 & -0.0475 & -0.0447 \\
\hline \multirow[t]{2}{*}{ INDHHI } & $-0.0574^{* * *}$ & $-0.0453^{* * *}$ & $-0.0257^{* *}$ & $-0.030^{* *}$ \\
\hline & -0.0038 & -0.0056 & -0.0094 & -0.0096 \\
\hline \multirow[t]{2}{*}{ GDP } & 0.0004 & $0.0023^{* *}$ & 0.0015 & 0.0012 \\
\hline & -0.0009 & -0.0009 & -0.0011 & $(0.00100$ \\
\hline \multirow[t]{2}{*}{ INFL } & $-0.0017^{* *}$ & $-0.0013^{* *}$ & 0 & 0 \\
\hline & -0.0007 & -0.0006 & -0.0005 & -0.0005 \\
\hline \multirow[t]{2}{*}{ LR } & -0.0046 & -0.0043 & $-0.0063^{* *}$ & $-0.004^{* *}$ \\
\hline & -0.003 & -0.0027 & -0.0027 & -0.0026 \\
\hline Constant & -0.5853 & -0.7331 & -0.6201 & -0.4767 \\
\hline $\operatorname{Adj} R$ & 0.3015 & 0.2817 & & \\
\hline F Stat & 120.73 & 50.88 & & \\
\hline \multicolumn{5}{|l|}{ Abond } \\
\hline \multicolumn{2}{|l|}{ Wald chi $^{2}$} & & $826.62^{* * *}$ & $135.42^{* *}$ \\
\hline \multicolumn{2}{|l|}{ Sargan test } & & 0.237 & 0.614 \\
\hline \multicolumn{2}{|l|}{ Hausman test } & $49.56^{* * *}$ & & \\
\hline
\end{tabular}

Standard errors are given in parentheses

$*, * * * *$ Show significance at 90,95 , and $99 \%$, respectively

LEV is the leverage measured through the ratio of debt to asset. PROF is the profitability measured through the ratio of return on equity. SIZE is the firm's size measured through natural log of firm's asset. NWC is the networking capital used as a proxy for a firm's liquidity. OC5\% is the ownership concentration. NDTS is thenon-debt tax shield measured through the proportion of the sum of amortization and depreciation to total assets. BSIZE is the board size measured through number of directors on a firm's board of directors. MTB is the market to book ratio used as a proxy for growth oppurtunities. TR is the tax to earnings ratio used a proxy for corporate tax rate, and it is measured as proportion of taxes to earnings before taxes. INDLEV is the median industry leverage as median of total debt to total asset ratios of involved companies in an industry. INDLIQ is the industry liquidity. INDHHI is Herfindahl-Hirschman Index (HHI) as the sum of the squares of a firm's sales to an industry's total sales. GDP is the real annual gross domestic product. INFL is the inflation rate in China. LR is the lending rate in China 
Table 5 Regression output for non-state-owned enterprises

\begin{tabular}{|c|c|c|c|c|}
\hline & OLS & GLS fixed-effects & GMM1 & GMM2 \\
\hline \multirow[t]{2}{*}{$\operatorname{LEV}(L 1)$} & & & $0.6381^{* * *}$ & $0.5994^{* * *}$ \\
\hline & & & -0.0315 & -0.0569 \\
\hline \multirow[t]{2}{*}{ PROF } & $-0.0518^{* *}$ & $-0.0510^{* *}$ & $-0.0423^{*}$ & $-0.0514^{* *}$ \\
\hline & -0.016 & -0.0158 & -0.0275 & -0.0275 \\
\hline \multirow[t]{2}{*}{ SIZE } & $0.0410^{* * *}$ & $0.0393^{* * *}$ & $0.0312^{* * *}$ & $0.0301^{* * *}$ \\
\hline & -0.0022 & -0.0033 & -0.0066 & -0.0071 \\
\hline \multirow[t]{2}{*}{ NWC } & $-0.051^{* * *}$ & $-0.0393^{* *}$ & -0.0063 & -0.014 \\
\hline & -0.0092 & -0.0117 & -0.0207 & -0.0213 \\
\hline \multirow[t]{2}{*}{ OC5\% } & $-0.0048^{* *}$ & $-0.0033^{* *}$ & -0.0004 & -0.0009 \\
\hline & -0.0011 & -0.0013 & -0.0019 & -0.002 \\
\hline \multirow[t]{2}{*}{ NDTS } & -0.0005 & -0.0005 & -0.0523 & -0.0753 \\
\hline & -0.0003 & -0.0004 & -0.1607 & -0.1608 \\
\hline \multirow[t]{2}{*}{ BSIZE } & -0.0059 & -0.0008 & -0.0004 & -0.0002 \\
\hline & -0.0017 & -0.0016 & -0.0004 & -0.0004 \\
\hline \multirow[t]{2}{*}{ MTB } & $0.0008^{* * *}$ & 0.0007 & 0.0014 & 0.0016 \\
\hline & -0.0008 & -0.0007 & -0.0021 & -0.002 \\
\hline \multirow[t]{2}{*}{ TR } & -0.0007 & -0.5752 & -0.0004 & 0.0002 \\
\hline & -0.0309 & -0.0428 & -0.0012 & -0.0011 \\
\hline \multirow[t]{2}{*}{ INDLEV } & $0.64^{* * *}$ & $0.573^{* * *}$ & $0.4519^{* * *}$ & $0.4642^{* * *}$ \\
\hline & -0.0147 & -0.0296 & -0.077 & -0.0798 \\
\hline \multirow[t]{2}{*}{ LNDLIQ } & -0.004 & $-0.1031^{* *}$ & -0.0142 & -0.0174 \\
\hline & -0.1449 & -0.115 & -0.0383 & -0.0393 \\
\hline \multirow[t]{2}{*}{ INDHHI } & $-0.050^{* * *}$ & $-0.0319^{* * *}$ & -0.0056 & -0.0053 \\
\hline & -0.0038 & -0.0055 & -0.0072 & -0.0072 \\
\hline \multirow[t]{2}{*}{ GDP } & $0.0004^{*}$ & $0.0022^{* *}$ & $0.0020^{*}$ & $0.0019^{* *}$ \\
\hline & -0.0009 & -0.0008 & -0.0011 & -0.0011 \\
\hline \multirow[t]{2}{*}{ INFL } & -0.0001 & -0.0003 & $-0.0008^{* *}$ & -0.0007 \\
\hline & -0.0007 & -0.0006 & -0.0005 & -0.0005 \\
\hline \multirow[t]{2}{*}{$L R$} & -0.0007 & $-0.0085^{* *}$ & -0.0038 & -0.0039 \\
\hline & -0.003 & -0.0026 & -0.0027 & -0.0027 \\
\hline Constant & -0.4816 & -0.523 & -0.6262 & -0.5921 \\
\hline Adj $R$ & 0.2726 & 0.2461 & & \\
\hline F Stat & 113.56 & 41.34 & & \\
\hline \multicolumn{5}{|l|}{ Abond test } \\
\hline Wald chi ${ }^{2}$ & & & $730.58^{* * *}$ & $194.9^{* * *}$ \\
\hline Sargan test & & & 0.397 & 0.418 \\
\hline Hausman test & & $49.32^{* * *}$ & & \\
\hline
\end{tabular}

Standard errors are given in parentheses

$*, * * * *$ Show significance at 90,95 , and $99 \%$, respectively

LEV is the leverage measured through the ratio of debt to asset. PROF is the profitability measured through the ratio of return on equity. SIZE is the firm's size measured through natural log of firm's asset. NWC is the networking capital used as a proxy for a firm's liquidity. OC5\% is the ownership concentration. NDTS is thenon-debt tax shield measured through the proportion of the sum of amortization and depreciation to total assets. BSIZE is the board size measured through number of directors on a firm's board of directors. MTB is the market to book ratio used as a proxy for growth oppurtunities.TR is the tax to earnings ratio used a proxy for corporate tax rate, and it is measured as proportion of taxes to earnings before taxes. INDLEV is the median industry leverage as median of total debt to total asset ratios of involved companies in an industry. INDLIQ is the industry liquidity. INDHHI is Herfindahl-Hirschman Index (HHI) as the sum of the squares of a firm's sales to an industry's total sales. GDP is the real annual gross domestic product. INFL is the inflation rate in China. LR is the lending rate in China 
Similarly, columns 3 and 4 of Table 5 represent GMM results for non-state-owned enterprises. Table 5 shows that adjustment coefficient for non-state-owned enterprises is $0.37(1-63)$ and $0.46(1.52)$ with respect to GMM1 and GMM2, respectively. Both of the dynamic panel data models report a higher adjustment coefficient for state-owned enterprises than non-state-owned enterprises. This shows that state-owned enterprises are faster in their adjustment policy of capital structure and takes less time than nonstate-owned enterprises to adjust to a target level of capital structure. One reason might be the pecking order of loans by banks towards state-owned enterprises. And because of easy access and prevalent bank loans in the market, state-owned enterprises might be rapid in achieving a target level of capital structure. Poncet et al. (2010) argue that capital market imperfections are prevalent in Chinese capital markets. Until 1998, the largest Chinese banks (most of them were state owned) were advised not to give credit to Chinese private companies. It was because of low political stature of these companies. Since 1998, these impediments in financing due to political pecking order should have been alleviated. However, research evidence suggests that financing constraints for private Chinese companies are still there due to social and political factors (Huang 2003). Thus, state-owned enterprises have easy access to bank loans and this might account for their high speed of adjustment. The institutional environment and unique Chinese market setting, in the context of state ownership, state-owned firms are at ease to raise or shed funds for a speedy adjustment to an optimal leverage. However, the implications of institutional environment are all too different for non-stateowned firms. The political and social pecking order towards SOEs, and limited financing alternatives, slow up the adjustment speed for non-state-owned enterprises. Two different approaches and alternatives to adjust leverage to an optimal level have important consideration for both managers (especially in NSOEs) and regulators. Regulating bodies should harmonize the legal system and ensure the equal access to financing alternatives.

\section{Multilevel determinants of capital structure in China Firm-specific determinants (overall firms)}

The discussion focuses on columns 1 and 2 of Tables 3 and 5. OLS and GLS fixed-effects coefficients in Table 3 for overall firms report a positive and significant coefficient for size while a negative and statistically significant coefficient for growth opportunities. Faulkender and Wang (2006) reported size as a measurement for financial constraints. Large firms with higher growth opportunities are at ease as far as funds accessibility and availability is concerned. One important finding for overall firm is the negative and statistically significant coefficient of ownership concentration. Moreover, board size (BSIZE) also reports a positive and significant coefficient. Berger et al. (1997) and Deesomsak et al. (2004) argue that larger companies with high concentration and large board size have a reduced disciplinary role of debt. Ownership concentration is found to have a negative relationship with leverage for overall firms (Table 3). This shows that the agency mechanism is associated with decreased risk since ownership concentration in Chinese firms is very high. This is in accordance with the explanation provided by Wiwattanakantang (1999).

Large shareholders instill an active monitoring and control mechanism, which results in reduced the debt level. Market to book ratio or growth opportunities show a positive 
relationship and it implies that Chinese firms used debt as prefer mode of financing to finance their future projects Chen (2004).

Table 3 indicates that tax rate (TR) has significant positive effect on leverage. This shows that optimal debt level is the increasing function of corporate tax rate (Scott 1976). A significant reason for firms' preference of debt over equity is tax shield attained through interest payments (Modigliani and Miller 1963).

\section{Firm-specific determinants (SOEs and NSOEs)}

The discussion of firm-specific determinants for SOEs and NSOEs focuses on columns 1 and 2 of Tables 4 and 5. Profitability and firm liquidity (NWC) have significant negative effect on the leverage policy of SOEs and NSOEs. This implies that both SOEs and NSOEs depend on internal source of financing before going for debt financing. Firm size and tax to earnings ratio report a significant positive effect on leverage for both SOEs and NSOEs. However, the effect of tax to earning (TR) is not statistically significant in the case of a non-state-owned enterprise. Size emancipates the fact that bigger firms enjoy a reputation and have access to financing alternatives. The positive tax rate and leverage relationship instills the insight of greater tax shield in case of debt financing. Ownership concentration (OC5\%) shows a statistically significant negative relationship with leverage, confirming the monitoring role of the largest shareholders in curtailing the leverage level. This negative effect of ownership concentration on leverage is reported both for SOEs and NSOEs. Tables 4 and 5 indicate that board size (BSIZE) has a negative effect on leverage for both SOEs and NSOEs. However, this relationship lacks statistical significance. Growth opportunities (MTB) report a negative relationship with leverage for both SOEs and NSOEs, thus indicating the use of high leverage of both SOEs and NSOEs to finance their future projects.

\section{Industry-specific determinants (overall, SOEs, and NSOEs)}

The discussion focuses on columns 1 and 2 of Tables 3, 4, and 5 for overall firms, SOEs, and NSOEs respectively. Table 3 suggests a strong positive relationship between industry leverage (INDLEV) and leverage of the firm for overall firms, SOEs, and NSOEs. This relationship is statistically significant in almost all the regressions. This shows that firm leverage shows an increasing trend as industry leverage increases and vice versa. Industry liquidity (INDLIQ) reports a negative relationship with firm leverage for all the regressions model; however, the relationship is not statically significant.

Although the negative relationship implies that in time of high liquidity, Chinese firms prefer internal sources and do not issue debt to finance their investments. Industry concentration (INDHHI) is found to have a negative relationship with firm leverage. The relationship is statistically significant for overall firms, SOEs, and NSOEs.

This relationship can be due to different characteristics of industries based on industry concentration. Firms in highly concentrated industries have higher size and profitability and have usually higher risk profile (MacKay and Phillips 2005). This higher risk can be related to the incentives provided to equity holders in case of high bankruptcy chances due to higher risk (Brander and Lewis (1986). This accounts for the negative relationship between industry concentration and leverage of the firm. 


\section{Country-level determinants of leverage (overall, SOEs, and NSOEs)}

The discussion for country-level determinants focuses on columns 1 and 2 of Tables 3, 4, and 5. Gross domestic product (GDP) is found to have a positive impact on firm leverage. This relationship accounts for overall firms, SOEs, and NSOEs and has statistical significance. This is in accordance with De Jong et al. (2008) who suggested a positive relationship between capital structure and GDP. They argued that firms in countries having better legal environment and having healthier growth rate are likely to take more debts. Inflation shows a negative relationship with the leverage policy of China, but it has mixed statistical significance. For inflation, two of the models (Table 3) show significance for overall firms, while one shows significance for state-owned firms; however, for NSOEs, this negative relationship lacks statistical significance. Inflation (INF) is found to have a negative relationship with the leverage policy of Chinese firms. This relationship accounts for overall, SOEs, and NSOEs. A negative and statistically significant effect (Tables 3, 4, and 5) is exhibited by lending rate (LR) on debt financing of Chinese firms. This is in accordance with the findings of Muradoglu and Sivaprasad (2011) who empirically found that leverage and lending rate are negatively related. These findings indicate a significant impact of country-specific indicators on Chinese firms and thus have important policy implications for managers with respect to different economic indicators of the country.

\section{Robustness}

Tables 6, 7, 8, 9, and 10 correspond to robustness analysis. Table 6 represents results for two-step GMM regressions for ownership concentration of the largest shareholders (1\%). GMM1 in Table 6 is the Arellano and Bover (1995) dynamic panel data model; while GMM2 is the Blundell and Bond (2000) dynamic panel data model, and GMM3 is the Elsas and Florysiak (2015) fractional-dependent variable dynamic panel data technique. Comparing the results of Table 6 with the results obtained in Table 5, it can be concluded that even after including the ownership concentration of the single largest shareholders, the speed of adjustment is not affected significantly. The coefficients of Table 6 (0.653 and 0.671) are very close to the coefficients in Table 5 (0.67 and 0.70).

Table 7 shows the results for one-step GMM regression while incorporating the ownership concentration of the single largest shareholders. The GMM1 and GMM2 results for both ownership concentration (OC1\% and OC5 \%) are almost similar. Both GMM1s for OC1\% and OC5\% results in the same coefficients of 0.652 (see Table 7). Similarly, GMM2 reports similar coefficient of 0.653 for both OC1\% and OC5\% (see Table 7).

Tables 7, 8, and 9 correspond to results for state-owned and non-state-owned enterprises. The first two columns of Tables 7, 8, and 9 indicate results for one-step GMM regression, while the remaining two columns of Tables 7, 8, and 9 refer to results for two-step GMM regressions. Comparing the coefficients of Tables 7, 8, and 9 with the coefficients of Tables 4 and 5, it can be inferred that even after incorporating the ownership concentration of the single largest shareholders, the adjustment rate of leverage is higher for state-owned enterprises as compared to that of non-state-owned enterprises. The results indicate that SOEs are faster in adjusting their policy indicating the influence of abundant debt-raising opportunities for them in the Chinese market. The marginal contribution about SOEs and NSOEs has significant implications, since we try to explain them in the context of political pecking order of debt financing by banks 
Table 6 Two-step GMM regression results for OC1\%

\begin{tabular}{|c|c|c|c|}
\hline & GMM1 & GMM2 & GMM3 \\
\hline \multirow[t]{2}{*}{ LEV(L1) } & $0.653^{* * *}$ & $0.671^{* * *}$ & $0.653^{* *}$ \\
\hline & -0.018 & -0.032 & -0.011 \\
\hline \multirow[t]{2}{*}{ PROF } & $-0.029^{* * *}$ & $-0.028^{* *}$ & $-0.013^{*}$ \\
\hline & -0.011 & -0.011 & -0.008 \\
\hline \multirow[t]{2}{*}{ SIZE } & 0.026 & $0.026^{* * *}$ & $0.042^{* * *}$ \\
\hline & -0.003 & -0.004 & -0.002 \\
\hline \multirow[t]{2}{*}{ NWC } & -0.006 & 0 & 0.002 \\
\hline & -0.014 & -0.014 & -0.008 \\
\hline \multirow[t]{2}{*}{ OC1\% } & 0 & 0 & 0 \\
\hline & 0 & 0 & 0 \\
\hline \multirow[t]{2}{*}{ NDTS } & 0.01 & 0.012 & 0.016 \\
\hline & -0.001 & -0.004 & 0 \\
\hline \multirow[t]{2}{*}{ BSIZE } & 0 & 0 & 0 \\
\hline & 0 & 0 & 0 \\
\hline \multirow[t]{2}{*}{ MTB } & 0.001 & 0 & -0.001 \\
\hline & -0.001 & -0.001 & -0.001 \\
\hline \multirow[t]{2}{*}{ TR } & 0 & 0 & 0 \\
\hline & 0 & 0 & 0 \\
\hline \multirow[t]{2}{*}{ INDLEV } & $0.316^{* *}$ & $0.335^{* * *}$ & $0.252^{* * *}$ \\
\hline & -0.046 & -0.047 & -0.027 \\
\hline \multirow[t]{2}{*}{ LNDLIQ } & 0.018 & 0.013 & -0.016 \\
\hline & -0.024 & -0.027 & -0.02 \\
\hline \multirow[t]{2}{*}{ INDHHI } & -0.013 & $-0.012^{* *}$ & $-0.034^{* *}$ \\
\hline & -0.005 & -0.005 & -0.003 \\
\hline \multirow[t]{2}{*}{ GDP } & $0.002^{* *}$ & $0.002^{* *}$ & $0.005^{* * *}$ \\
\hline & -0.001 & -0.001 & -0.001 \\
\hline \multirow[t]{2}{*}{ INFL } & $-0.001^{* *}$ & $-0.001^{* *}$ & $-0.001^{* *}$ \\
\hline & 0 & 0 & 0 \\
\hline \multirow[t]{2}{*}{ LR } & $-0.004^{* *}$ & $-0.004^{* *}$ & $-0.013^{* *}$ \\
\hline & -0.001 & -0.001 & -0.002 \\
\hline Constant & $-0.471^{* * *}$ & $-0.47^{* * *}$ & $-0.52^{* * *}$ \\
\hline Abond test & 0.175 & 0.185 & 0.135 \\
\hline Sargan test & 0.32 & 0.219 & 0.147 \\
\hline Wald chi ${ }^{2}$ & 131.02 & 178.21 & 133.15 \\
\hline
\end{tabular}

Standard errors are given in parentheses

* ******Show significance at 90,95 , and $99 \%$, respectively

LEV is the leverage measured through the ratio of debt to asset. PROF is the profitability measured through the ratio of return on equity. SIZE is the firm's size measured through natural log of firm's asset. NWC is the networking capital used as a proxy for a firm's liquidity. OC5\% is the ownership concentration. NDTS is thenon-debt tax shield measured through the proportion of the sum of amortization and depreciation to total assets. BSIZE is the board size measured through number of directors on a firm's board of directors. MTB is the market to book ratio used as a proxy for growth oppurtunities. TR is the tax to earnings ratio used a proxy for corporate tax rate, and it is measured as proportion of taxes to earnings before taxes. INDLEV is the median industry leverage as median of total debt to total asset ratios of involved companies in an industry. INDLIQ is the industry liquidity. INDHHI is Herfindahl-Hirschman Index (HHI) as the sum of the squares of a firm's sales to an industry's total sales. GDP is the real annual gross domestic product. INFL is the inflation rate in China. LR is the lending rate in China 
Table 7 One-step GMM regression results

\begin{tabular}{|c|c|c|c|c|}
\hline & \multirow[t]{2}{*}{ GMM1 } & \multirow[t]{2}{*}{ GMM2 } & \multicolumn{2}{|l|}{ OC5\% } \\
\hline & & & $\overline{G M M 1}$ & GMM2 \\
\hline \multirow[t]{2}{*}{ LEV(L1) } & $0.655^{* * *}$ & $0.632^{* * *}$ & $0.655^{* * *}$ & $0.630^{* * *}$ \\
\hline & -0.026 & -0.013 & -0.025 & -0.012 \\
\hline \multirow[t]{2}{*}{ PROF } & $-0.037^{* * *}$ & $-0.03^{* * *}$ & $-0.03^{* * *}$ & $-0.03^{* * *}$ \\
\hline & -0.008 & -0.007 & -0.008 & -0.007 \\
\hline \multirow[t]{2}{*}{ SIZE } & $0.033^{* * *}$ & $0.032^{* * *}$ & $0.033^{* * *}$ & $0.033^{* * *}$ \\
\hline & -0.003 & -0.003 & -0.003 & -0.003 \\
\hline \multirow[t]{2}{*}{ NWC } & -0.004 & -0.005 & -0.004 & -0.005 \\
\hline & -0.01 & -0.01 & -0.01 & -0.01 \\
\hline \multirow[t]{2}{*}{ OC } & 0.001 & 0.002 & 0.001 & 0.001 \\
\hline & 0 & 0 & -0.001 & -0.001 \\
\hline \multirow[t]{2}{*}{ NDTS } & 0.003 & 0.001 & 0.007 & 0.009 \\
\hline & -0.001 & -0.001 & -0.003 & -0.001 \\
\hline \multirow[t]{2}{*}{ BSIZE } & 0.001 & 0.002 & 0.001 & 0.002 \\
\hline & 0 & 0 & 0 & 0 \\
\hline \multirow[t]{2}{*}{ MTB } & 0.001 & 0.001 & 0.001 & 0.001 \\
\hline & -0.001 & -0.001 & -0.001 & -0.001 \\
\hline \multirow[t]{2}{*}{ TR } & 0.001 & 0.0003 & 0.002 & 0.001 \\
\hline & 0 & 0 & 0 & 0 \\
\hline \multirow[t]{2}{*}{ INDLEV } & $0.335^{* *}$ & $0.322^{* * *}$ & $0.335^{* * *}$ & $0.321^{* *}$ \\
\hline & -0.04 & -0.038 & -0.04 & -0.038 \\
\hline \multirow[t]{2}{*}{ LNDLIQ } & $-0.054^{* *}$ & $-0.063^{* *}$ & $-0.052^{* *}$ & $-0.061^{* *}$ \\
\hline & -0.028 & -0.026 & -0.028 & -0.025 \\
\hline \multirow[t]{2}{*}{ INDHHI } & $-0.019^{* * *}$ & $-0.018^{* *}$ & $-0.019^{* *}$ & $-0.018^{* *}$ \\
\hline & -0.004 & -0.004 & -0.004 & -0.004 \\
\hline \multirow[t]{2}{*}{ GDP } & $0.003^{* * *}$ & $0.003^{* * *}$ & $0.003^{* * *}$ & $0.003^{* * *}$ \\
\hline & -0.001 & -0.001 & -0.001 & -0.001 \\
\hline \multirow[t]{2}{*}{ INFL } & $-0.001^{* *}$ & $-0.001^{* *}$ & $-0.001^{* *}$ & $-0.001^{* *}$ \\
\hline & 0 & 0 & 0 & 0 \\
\hline \multirow[t]{2}{*}{$L R$} & $-0.009^{* *}$ & $-0.009^{* *}$ & $-0.009^{* *}$ & $-0.009^{* *}$ \\
\hline & -0.002 & -0.001 & -0.002 & -0.001 \\
\hline Constant & $-0.56^{* * *}$ & $-0.55^{* * *}$ & $-0.57^{* * *}$ & $-0.56^{* * *}$ \\
\hline Abond test & 0.125 & 0.147 & 0.232 & 0.261 \\
\hline Sargan test & 0.561 & 0.784 & 0.217 & 0.328 \\
\hline Wald chi ${ }^{2}$ & 1014.21 & 596.09 & 783.21 & 794.13 \\
\hline
\end{tabular}

Standard errors are given in parentheses

$*$, **,**Show significance at 90,95 , and $99 \%$, respectively

LEV is the leverage measured through the ratio of debt to asset. PROF is the profitability measured through the ratio of return on equity. SIZE is the firm's size measured through natural log of firm's asset. NWC is the networking capital used as a proxy for a firm's liquidity. OC5\% is the ownership concentration. NDTS is thenon-debt tax shield measured through the proportion of the sum of amortization and depreciation to total assets. BSIZE is the board size measured through number of directors on a firm's board of directors. MTB is the market to book ratio used as a proxy for growth oppurtunities. TR is the tax to earnings ratio used a proxy for corporate tax rate, and it is measured as proportion of taxes to earnings before taxes. INDLEV is the median industry leverage as median of total debt to total asset ratios of involved companies in an industry. INDLIQ is the industry liquidity. INDHHI is Herfindahl-Hirschman Index (HHI) as the sum of the squares of a firm's sales to an industry's total sales. GDP is the real annual gross domestic product. INFL is the inflation rate in China. LR is the lending rate in China 
Table 8 Regression results for state-owned enterprises for OC1\%

\begin{tabular}{|c|c|c|c|c|}
\hline & \multicolumn{2}{|l|}{ One step } & \multicolumn{2}{|c|}{ Two steps } \\
\hline & GMM1 & GMM2 & GMM1 & GMM2 \\
\hline \multirow[t]{2}{*}{$\mathrm{LEV}(\mathrm{L} 1)$} & $0.591^{* * *}$ & $0.521^{* * *}$ & $0.593^{* * *}$ & $0.513^{* * *}$ \\
\hline & -0.034 & -0.018 & -0.037 & -0.024 \\
\hline \multirow[t]{2}{*}{ PROF } & $-0.028^{* *}$ & $-0.027^{* *}$ & $-0.025^{* *}$ & $-0.022^{* *}$ \\
\hline & -0.01 & -0.01 & -0.01 & -0.01 \\
\hline \multirow[t]{2}{*}{ SIZE } & $0.027^{* * *}$ & $0.027^{* * *}$ & $0.024^{* * *}$ & $0.022^{* *}$ \\
\hline & -0.004 & -0.004 & -0.004 & -0.004 \\
\hline \multirow[t]{2}{*}{ NWC } & $-0.006^{* *}$ & $-0.006^{* *}$ & $-0.013^{* *}$ & $-0.014^{* *}$ \\
\hline & -0.013 & -0.013 & -0.016 & -0.016 \\
\hline \multirow[t]{2}{*}{ OC } & 0.001 & 0.001 & 0.002 & 0.002 \\
\hline & 0 & 0 & 0 & 0 \\
\hline \multirow[t]{2}{*}{ NDTS } & -0.255 & -0.215 & -0.214 & -0.159 \\
\hline & -0.107 & -0.11 & -0.126 & -0.121 \\
\hline \multirow[t]{2}{*}{ BSIZE } & 0.002 & 0.001 & 0.002 & 0.001 \\
\hline & 0 & 0 & 0 & 0 \\
\hline \multirow[t]{2}{*}{ MTB } & 0.001 & 0.001 & 0.001 & 0.001 \\
\hline & -0.001 & -0.001 & -0.001 & -0.001 \\
\hline \multirow[t]{2}{*}{$\mathrm{TR}$} & 0.001 & 0.002 & 0.001 & 0.002 \\
\hline & 0 & 0 & 0 & 0 \\
\hline \multirow[t]{2}{*}{ INDLEV } & $0.346^{* * *}$ & $0.375^{* *}$ & $0.394^{* * *}$ & $0.410^{* * *}$ \\
\hline & -0.057 & -0.057 & -0.063 & -0.06 \\
\hline \multirow[t]{2}{*}{ LNDLIQ } & $-0.080^{* * *}$ & $-0.085^{* *}$ & $-0.05^{* * *}$ & $-0.069^{* *}$ \\
\hline & -0.039 & -0.038 & -0.04 & -0.038 \\
\hline \multirow[t]{2}{*}{ INDHHI } & $-0.011^{* *}$ & $-0.012^{* *}$ & $-0.005^{* *}$ & $-0.004^{* *}$ \\
\hline & -0.005 & -0.005 & -0.006 & -0.006 \\
\hline \multirow[t]{2}{*}{ GDP } & $0.003^{* * *}$ & $0.003^{* * *}$ & $0.002^{* * *}$ & $0.002^{* * *}$ \\
\hline & -0.001 & -0.001 & -0.001 & -0.001 \\
\hline \multirow[t]{2}{*}{ INFL } & $-0.001^{* *}$ & $-0.001^{* *}$ & $-0.001^{* *}$ & $-0.001^{* *}$ \\
\hline & 0 & 0 & 0 & 0 \\
\hline \multirow[t]{2}{*}{ LR } & $-0.007^{* *}$ & $-0.007^{* *}$ & $-0.002^{* *}$ & $-0.002^{* *}$ \\
\hline & -0.002 & -0.002 & -0.002 & -0.002 \\
\hline Constant & -0.489 & -0.501 & -0.487 & -0.469 \\
\hline Sargen test & 0.249 & 0.179 & 0.478 & 0.343 \\
\hline Abond test & 0.125 & 0.239 & 0.614 & 0.398 \\
\hline Wild $\mathrm{Chi}^{2}$ & 1234.12 & 773.21 & 832.01 & 686.21 \\
\hline
\end{tabular}

Standard errors are given in parentheses

$*$, **,**Show significance at 90,95 , and $99 \%$, respectively

LEV is the leverage measured through the ratio of debt to asset. PROF is the profitability measured through the ratio of return on equity. SIZE is the firm's size measured through natural log of firm's asset. NWC is the networking capital used as a proxy for a firm's liquidity. OC5\% is the ownership concentration. NDTS is thenon-debt tax shield measured through the proportion of the sum of amortization and depreciation to total assets. BSIZE is the board size measured through number of directors on a firm's board of directors. MTB is the market to book ratio used as a proxy for growth oppurtunities. TR is the tax to earnings ratio used a proxy for corporate tax rate, and it is measured as proportion of taxes to earnings before taxes. INDLEV is the median industry leverage as median of total debt to total asset ratios of involved companies in an industry. INDLIQ is the industry liquidity. INDHHI is Herfindahl-Hirschman Index (HHI) as the sum of the squares of a firm's sales to an industry's total sales. GDP is the real annual gross domestic product. INFL is the inflation rate in China. LR is the lending rate in China 
Table 9 Regression results for non-state-owned enterprises for OC1\%

\begin{tabular}{|c|c|c|c|c|}
\hline & \multicolumn{2}{|l|}{ One step } & \multicolumn{2}{|l|}{ Two steps } \\
\hline & GMM1 & GMM2 & GMM1 & GMM2 \\
\hline \multirow[t]{2}{*}{ LEV(L1) } & $0.692^{* * *}$ & $0.653^{* * *}$ & $0.673^{* * *}$ & $0.685^{* * *}$ \\
\hline & -0.036 & -0.018 & -0.042 & -0.025 \\
\hline \multirow[t]{2}{*}{ PROF } & $-0.094^{* *}$ & $-0.088^{* *}$ & $-0.074^{* *}$ & $-0.067^{* *}$ \\
\hline & -0.016 & -0.015 & -0.025 & -0.024 \\
\hline \multirow[t]{2}{*}{ SIZE } & $0.042^{* *}$ & $0.042^{* *}$ & $0.026^{* *}$ & $0.032^{* *}$ \\
\hline & -0.004 & -0.004 & -0.007 & -0.006 \\
\hline \multirow[t]{2}{*}{ NWC } & $-0.030^{* *}$ & $-0.032^{* *}$ & $-0.005^{* *}$ & $-0.020^{* *}$ \\
\hline & -0.016 & -0.015 & -0.019 & -0.018 \\
\hline \multirow[t]{2}{*}{ OC } & 0.001 & 0.001 & 0.001 & 0.001 \\
\hline & 0 & 0 & 0 & 0 \\
\hline \multirow[t]{2}{*}{ NDTS } & -0.163 & -0.097 & -0.196 & -0.052 \\
\hline & -0.127 & -0.123 & -0.167 & -0.149 \\
\hline \multirow[t]{2}{*}{ BSIZE } & 0.001 & 0.001 & 0.001 & 0.001 \\
\hline & 0 & 0 & 0 & 0 \\
\hline \multirow[t]{2}{*}{ MTB } & 0.001 & 0.001 & -0.001 & -0.001 \\
\hline & -0.002 & -0.002 & -0.002 & -0.001 \\
\hline \multirow[t]{2}{*}{ TR } & 0 & 0 & 0 & 0 \\
\hline & -0.001 & -0.001 & 0 & 0 \\
\hline \multirow[t]{2}{*}{ INDLEV } & $0.334^{* * *}$ & $0.279^{* * *}$ & $0.317^{* * *}$ & $0.241^{* * *}$ \\
\hline & -0.055 & -0.051 & -0.06 & -0.055 \\
\hline \multirow[t]{2}{*}{ LNDLIQ } & $-0.031^{* *}$ & $-0.034^{* *}$ & $-0.028^{* *}$ & $-0.023^{* *}$ \\
\hline & -0.041 & -0.036 & -0.032 & -0.028 \\
\hline \multirow[t]{2}{*}{ INDHHI } & $-0.024^{* *}$ & $-0.024^{* *}$ & $-0.016^{* *}$ & $-0.020^{* *}$ \\
\hline & -0.007 & -0.007 & -0.008 & -0.007 \\
\hline \multirow[t]{2}{*}{ GDP } & $0.004^{* * *}$ & $0.004^{* * *}$ & $0.002^{* * *}$ & $0.003^{* *}$ \\
\hline & -0.001 & -0.001 & -0.001 & -0.001 \\
\hline \multirow[t]{2}{*}{ INFL } & $-0.001^{* *}$ & $-0.008^{* *}$ & $-0.005^{* *}$ & $-0.009^{* *}$ \\
\hline & 0 & 0 & 0 & 0 \\
\hline \multirow[t]{2}{*}{ LR } & $-0.011^{* *}$ & $-0.011^{* *}$ & $-0.015^{* *}$ & $-0.006^{* *}$ \\
\hline & -0.002 & -0.002 & -0.002 & -0.002 \\
\hline Constant & -0.712 & -0.703 & -0.674 & -0.516 \\
\hline Abond test & 0.217 & 0.871 & 0.478 & 0.357 \\
\hline Sargan test & 0.147 & 0.123 & 0.136 & 0.138 \\
\hline Wald $\mathrm{Chi}^{2}$ & 1132.23 & 1234.53 & 1478.32 & 1725.103 \\
\hline
\end{tabular}

Standard errors are given in parentheses

$*$, **, ***Show significance at 90,95 , and $99 \%$, respectively

LEV is the leverage measured through the ratio of debt to asset. PROF is the profitability measured through the ratio of return on equity. SIZE is the firm's size measured through natural log of firm's asset. NWC is the networking capital used as a proxy for a firm's liquidity. OC5\% is the ownership concentration. NDTS is thenon-debt tax shield measured through the proportion of the sum of amortization and depreciation to total assets. BSIZE is the board size measured through number of directors on a firm's board of directors. MTB is the market to book ratio used as a proxy for growth oppurtunities. TR is the tax to earnings ratio used a proxy for corporate tax rate, and it is measured as proportion of taxes to earnings before taxes. INDLEV is the median industry leverage as median of total debt to total asset ratios of involved companies in an industry. INDLIQ is the industry liquidity. INDHHI is Herfindahl-Hirschman Index (HHI) as the sum of the squares of a firm's sales to an industry's total sales. GDP is the real annual gross domestic product. INFL is the inflation rate in China. LR is the lending rate in China 
Table 10 ANOVA for SOEs and NSOES

\begin{tabular}{llccc}
\hline Variable & SOE & NSOEs & $F$ Value & Prob of $F$ \\
\hline Mean of leverage & 0.714 & 0.64 & 31.07 & 0.000 \\
\hline
\end{tabular}

towards SOEs and abundance of debt financing as the financing alternatives of Chinese firms. In this regard, these findings may provide some significant implications for policy makers to provide equal alternatives of financing for both SOEs and NSOEs. These results are consistent for both one-step and two-step GMM regression models.

\section{Conclusions}

This study tries to investigate the adjustment behavior of Chinese firms towards a target leverage ratio. For the purpose of robustness, this study uses three models of generalized method of moments. The study uses GMM's method of Arellano and Bover (1995)/Blundell and Bond (2000) and Elsas and Florysiak (2015) to estimate the dynamic equation. Along with the estimation of adjustment speed, the study investigates multilevel determinants of leverage policy in China. Furthermore, this study divides the sample into state-owned and non-state-owned enterprises to incorporate the effect of ownership type in the analysis. The findings for generalized method of moments show that all models indicate positive coefficients for lagged leverage, thus showing that Chinese firms follow target leverage. These results correspond to the findings of Rehman et al. (2016). They reported trade off behaviour of leverage policy for Chinese firms, using generalized method of moments. This also indicates that Chinese firms follow a trade-off policy towards leverage ratios. To make the results more plausible, this study divides the sample into two subsamples of state-owned and non-stateowned enterprises. Both the GMM models indicated that SOEs adjustment of leverage policy is faster than NSOEs. The underlying reason may be the pecking order followed by financial institutions towards SOEs. This makes SOEs to be at ease while issuing debt financing.

The study further investigates firm-level, industry-level, and country-level determinants of leverage in China. Firm-level determinants indicate that firm size has a significant positive effect on firm leverage. This is in line with the findings of Faulkender and Wang (2006) who reported size as a measurement for financial constraints. Large firms with higher growth opportunities are at ease as far as funds accessibility and availability are concerned. Ownership concentration is quite concentrated in China. The large shareholders have a disciplinary role in leverage policy of Chinese firms; thus, it shows a significant negative relationship with firm leverage in China. Profitability, firm liquidity (NWC), and non-debt tax shield shows a negative impact on firm leverage. However, NDTS lacks statistical significance. This implies that in time of high profitability and high firm liquidity, firms in China rely on internal sources of financing to finance their investment projects. Potential growth opportunities (MTB) are found to have a positive relationship with firm leverage, thus indicating that to finance their future investment opportunities, Chinese firms raise funds through debt financing.

At the industry level, industry leverage is found to have positive and statistically significant impact on firm leverage. This implies that firms in China follow industry-level leverage, and if it has an increasing trend, firms follow to raise more debt and advice 
versa. Industry liquidity shows a negative relationship towards the leverage in Chinese firms; however, this relationship lacks statistical significance. Industry concentration (INDHHI) shows a negative and statistically significant relationship with firm leverage, thus indicating that firms in concentrated industries tend to issue low debt and vice versa. This relationship can be due to different characteristics of industries based on industry concentration. Firms in highly concentrated industries have higher size and profitability and have usually higher risk profile (MacKay and Phillips 2005). This higher risk can be related to the incentives provided to equity holders in case of high bankruptcy chances due to higher risk (Brander and Lewis (1986)). This accounts for the negative relationship between industry concentration and leverage of the firm.

Among the country-level determinants investigated by this study, GDP is found to positively and significantly affect firm leverage. This implies that in times of an economic boom, Chinese firms try to raise more debt, thus reaping the benefits of good economic conditions of the country. This is in accordance with De Jong et al. (2008) who suggest a positive relationship between capital structure and GDP. They argue that countries having better legal environment and having healthier growth rate are likely to take more debt. Inflation shows a negative relationship with the leverage policy of China but it has mixed statistical significance. The relationship of inflation and leverage is although negative; however it lacks much statistical significance. Lending rate shows a negative relationship with the firm leverage. This implies that at the time of high lending rates, firms are reluctant to issue a debt to finance their investments. These findings are in accordance with Muradoglu and Sivaprasad (2011), who empirically found that leverage and lending rate are negatively related.

Overall results show that firm-level, industry-level, and country-level factors have serious implication for firm leverage in China. The loss of significance of various factors in GMM models accounts for the endogeneity of these factors. The use of generalized method of moments is used solely to estimate the dynamic nature of leverage policy in China. The findings suggest significant policy implications. In terms of adjustment behavior, the government needs to articulate the lending policy towards overall firms, avoiding the pecking order preference towards state-owned firms in China. Foreign researchers can get a very significant insight from this research paper. Generally, it will help foreign researchers to understand the peculiar and unique features of Chinese markets and the institutional environment prevalent in China. In particular, foreign researchers will benefit from this study to understand leverage policy and firm behavior to adjust to an optimal leverage policy. Furthermore, information and empirical findings provided by this study regarding SOEs and NSOEs are of significant importance. These findings can be extrapolated to form foundations of studies constituting reforms in other countries.

Similarly, managers in firms can get useful insight from these findings keeping their leverage in line with various factors such as industry average leverage and liquidity of firm as well as the industry. Industry concentration is providing extra ease to firms to raise more debts thus giving them an advantage. A regulatory body should seek to curtail that concentration, providing equal debt-raising opportunities to all the firms and thus avoiding the monopolistic debt raising. 


\section{Abbreviations}

BSIZE: Board size; GDP: Gross domestic product; GMM: Generalized method of moments; INDHHI: Industry Hirschman Herfindhal Index; INDLEV: Industry leverage; INDLIQ: Industry liquidity; INFL: Inflation rate; LEV: Leverage; LR: Lending rate; NDTS: Non-debt tax shield; NSOEs: Non-state-owned enterprises; NWC: Networking capital; OC1\%: Ownership concentration of the single largest shareholders; OC5\%: Ownership concentration of the five largest shareholders; OLS: Ordinary least square; PROF: Profitability; SIZE: Size; SOEs: State-owned enterprises

Funding

There are no funding sources to conduct this study.

\section{Authors' contributions}

This study is conducted by AR, MW, and SSM to investigate the adjustment of leverage in Chinese firms. All the authors equally participated to conduct and write this research paper. All authors read and approved the final manuscript.

\section{Competing interests}

The authors declare that they have no competing interests.

\section{Author details}

${ }^{1}$ School of Accounting, Dongbei University of Finance and Economics, Dalian, People's Republic of China.

${ }^{2}$ International Business School, Zhejiang Gongshang University, Hangzhou 310018, People's Republic of China.

Received: 3 January 2017 Accepted: 10 May 2017

\section{Published online: 27 May 2017}

\section{References}

Adrian T, Boyarchenko N (2015) Intermediary Leverage Cycles and Financial Stability, Federal Reserve Bank of New York Staff Reports, no. 567

Alves PFP, Ferreira MA (2011) Capital structure and law around the world. J Multinational Financ Manag 21(3):119-150

Andrade G, Kaplan SN (1998) How costly is financial (not economic) distress? Evidence from highly levered transactions that became distressed. J Finance 53:1443-1493

Ang JS, Fatemi A, Tourani-Rad A (1997) Capital structure and dividend policies of Indonesian firms. Pac Basin Financ J 5:87-103

Arellano M, Bover O (1995) Another look at the instrumental variable estimation of error-components models. J Econ 68:29-51

Baker M, Wurgler J (2002) Market timing and capital structure. J Financ 57:1-32

Berger PG, Ofek E, Yermack DL (1997) Managerial entrenchment and capital structure decisions. J Financ 52(4):1411-1438

Bessler W, Drobetz W, Pensa P (2008) Do managers adjust the capital structure to market value changes? Evidence from Europe, Zeitschrift f€ur Betriebswirtschaft Special Issue 6., pp 113-145

Bevan A, Danbolt J (2002) Capital structure and its determinants in the UK: A decompositional analysis. Appl Financ Econ 12(3):159-170

Blundell R, Bond S (2000) GMM estimation with persistent panel data: an application to production functions. Econ Rev 19(3):321-340

Bowen RM, Daley LA, Huber CC (1982) Evidence on the existence and determinants of inter-industry differences in leverage. Financ Manag 11(4):10-20

Bradley M, Jarrell GA, Kim HE (1984) On the existence of an optimal capital structure: Theory and evidence. J Financ 39 857-878

Brander J, Lewis T (1986) Oligopoly and financial structure: The limited liability effect. Am Econ Rev 76:956-970

Brandt L, Li H (2003) Bank discrimination in transition economies: ideology, information, or incentives? J Comp Econ 31(3):387-413, Elsevier

Bris A, Welch I, Zhu N (2006) The cost of bankruptcy: Chapter 11 Liquidation versus Chapter 7 Reorganization. J Financ 61:1253-1303

Byoun S (2008) How and when do firms adjust their capital structures towards targets? J Financ 63:3069-3095

Byoun S, Xu Z (2013) Why do some firms go debt free? Asia-Pac J Financ Stud 42:1-38

Chakraborty I (2010) Capital structure in an emerging stock market: The case of India. Res Int Bus Financ 24:295-314

Chang RP, Rhee SG (1990) The impact of personal taxes on corporate dividend policy and capital structure decisions. Financ Manag 19(2):21-31

Chen JJ (2004) Determinants of capital structure of Chinese-listed companies. J Bus Res 57(12):1341-1351

Cheng SR, Shiu CY (2007) Investor protection and capital structure: International evidence. J Multinational Financ Manag 17(1):30-44

Colombage SR (2005) Sectoral analysis of corporate capital structure choice - Emerging market evidence from Sri Lanka. J Asia Pac Bus 6(3):5-35

Cook DO, Tang T (2010) Macroeconomic conditions and capital structure adjustment speed. J Corp Finan 16(1):73-87, http://doi.org/10.1016/j.jcorpfin.2009.02.003

De Jong A, Kabir R, Nguyen TT (2008) Capital structure around the world: The roles of firm- and countryspecific determinants. J Bank Financ 32(9):1954-1969

Deesomsak R, Paudyal K, Pescetto G (2004) The determinants of capital structure: evidence from the Asia Pacific region. J Multinational Financ Manag 14(4):387-405

Donaldson G (1961) Corporate debt capacity: A study of corporate debt policy and the determination of corporate debt capacity. Harvard Graduate School of Business Administration, Boston 
Duan H, bin Chik AR, Liu C (2012) Institutional Environment and Capital Structure: Evidence from Private Listed Enterprises in China. Int J Financ Res 3(1). http://doi.org/10.5430/ijfr.v3n1p15. Accessed 23 Aug 2016

Elsas R, Florysiak D (2015) Dynamic Capital Structure Adjustment and the Impact of Fractional Dependent Variables. J Financ Quant Anal 50(5):1105-1133

Faccio M, Masulis RW, McConnell JJ (2006) Political Connections and Corporate Bailouts. J Financ 61:2597-2635. doi:10.1111/j.1540-6261.2006.01000.x

Fama EF, French KR (2002) Testing tradeoff and pecking order predictions about dividends and debt. Rev Financ Stud 15:1-33

Fan DK, So RW (2004) What managers think about capital structure: The evidence from Hong Kong. J Asian Econ 15:817-830

Fan JPH, Titman S, Twite GJ (2008) An international comparison of capital structure and debt maturity choices. AFA 2005 Philadelphia Meetings Paper, United States

Fattouh B, Scaramozzino P, Harris L (2005) Capital structure in South Korea: A quantile regression approach. J Dev Econ 76:231-250

Faulkender M, Wang R (2006) Corporate financial policy and the value of cash. J Financ 61(4):1957-1990

Fischer EO, Heinkel R, Zechner J (1989) Dynamic capital structure choice: Theory and tests. J Financ 44:19-40

Flannery MJ, Hankins KW (2007) A theory of capital structure adjustment speed, Working paper. University of Florida and University of Kentucky, USA

Flannery MJ, Rangan KP (2006) Partial adjustment toward target capital structures. J Financ Econ 79:469-506

Frank MZ, Goyal VK (2003) Testing the pecking order theory of capital structure. J Financ Econ 67:217-248

Frank MZ, Goyal VK (2008) Chapter 12 - Trade-Off and Pecking Order Theories of Debt* A2 - Eckbo, B. Espen. In: Handbook of Empirical Corporate Finance. Elsevier, San Diego, pp 135-202, Retrieved from http://www. sciencedirect.com/science/article/pii/B9780444532657500044

Getzmann A, Lang S, Spremann K (2014) Target Capital Structure and Adjustment Speed in Asia. Asia-Pacif J Financ Stud 43(1):1-30, http://doi.org/10.1111/ajfs.12038

Guney Y, Li L, Fairchild R (2011) The relationship between product market competition and capital structure in Chinese listed firms. Int Rev Financ Anal 20:41-51

Guo L, Smallman C, Radford J (2013) A critique of corporate governance in China. Int J Law Manag 55(4):257-272. doi:10.1108/IJLMA-10-2011-0012

Halov N, Heider F (2006) Capital structure, risk and asymmetric information, SSRN Working Paper. EFA 2004, Maastricht

Hennessy CA, Whited TM (2007) How Costly is External Financing? Evidence from a Structural Estimation. J Financ 62:1705-1745

Hovakimian A, Li G (2009) Do firms have unique target debt ratios to which they adjust? Working Paper. http://papers. ssrn.com/sol3/papers.cfm?abstract_id=1138316. Accessed 18 Jul 2016

Hovakimian A, Opler T, Titman S (2001) The debt-equity choice. J Financ Quant Anal 36:1-24

Huang M (2003) Liquidity shocks and equilibrium liquidity premia. J Econ Theory 109(1):104-129, http://doi.org/10. 1016/S0022-0531(02)00039-X

Huang R, Ritter JR (2009) Testing theories of capital structure and estimating the speed of adjustment. J Financ Quant Anal 44:237-271

Hubbard GR (1997) Capital Market Imperfection and Investment, NBER Working Paper Series

Jalilvand A, Harris RS (1984) Corporate behaviour in adjusting to capital structure and dividend targets: An econometric study. J Financ 39:127-145

Jensen MC (1986) Agency cost of free cash flow, corporate finance, and takeovers. Am Econ Rev 76(2). Retrieved from http://papers.ssrn.com/sol3/Papers.cfm?abstract_id=99580. Accessed 13 Sept 2016

Jung K, Kim B (2008) Corporate cash holdings and tax-induced debt financing. Asia-Pac J Financ Stud 37:983-1023

Juselius M, Drehmann M (2015) Leverage dynamics and the real burden of debt, BIS Working Papers No 501

Kayo EK, Kimura H (2011) Hierarchical determinants of capital structure. J Bank Financ 35(2):358-371, http://doi.org/10. 1016/j.jbankfin.2010.08.015

King MR, Santor E (2008) Family values: Ownership structure, performance and capital structure of Canadian firms. J Bank Financ 32(11):2423-2432

Korajczyk R, Levy A (2003) Capital structure choice: Macroeconomic conditions and financial constraints. J Financ Econ 68(1):75-109

Leary MT, Roberts MR (2005) Do firms rebalance their capital structures? J Financ 60:2575-2619

Leland HE, Toft KB (1996) Optimal capital structure, endogenous bankruptcy, and the term structure of credit spreads. J Financ 51:987-1019

Lemmon ML, Roberts MR, Zender JF (2008) Back to the beginning: Persistence and the cross-section of corporate capital structure. J Financ 63:1575-1608

MacKay P, Phillips GM (2005) How does industry affect firm financial structure? Rev Financ Stud 18(4):1433-1466

Miguel A, Pindado J (2001) Determinants of capital structure: New evidence from Spanish panel data. J Corp Finan 7:77-99

Modigliani F, Miller MH (1958) The cost of capital, corporation finance and the theory of investment. Am Econ Rev 48:261-297

Modigliani F, Miller MH (1963) Corporate income taxes and the cost of capital: A correction. Am Econ Rev 53:433-443

Muradoglu YG, Sivaprasad S (2011) Capital structure and abnormal returns. Int Bus Rev 21(3):328-341

Myers SC (1984) The capital structure puzzle. J Financ 39:575-592

Myers SC, Majluf NS (1984) Corporate financing and investment decisions when firms have information the investors do not have. J Financ Econ 13:187-221

Pandey IM (2001) Capital structure and the firm characteristics: Evidence from an emerging market, Working paper. Indian Institute of Management, Ahmedabad

Poncet S, Steingress W, Vandenbussche H (2010) Financial constraints in China: Firm-level evidence. China Econ Rev 21(3):411-422, http://doi.org/10.1016/j.chieco.2010.03.001 
Pound J, Zeckhauser R (1990) Clearly heard on the street: the effect of takeover rumors on stock prices. J Bus 63:291-318 Qian Y (1995) Reforming corporate governance and finance in China. In: Aoki M, Kim HK (eds) Corporate governance in transitional economies: Insider control and the role of banks. The International Bank for Reconstruction and Development, Washington, DC, pp 215-252

Rajan RG, Zingales L (1995) What do we know about capital structure? Some evidence from international data. J Financ 50:1421-1460

Rehman A, Wang M (2015) Corporate cash holdings and adjustment behaviour in Chinese firms: An empirical analysis using generalized method of moments. Australas Account Bus Finance J 9(4):20

Scott JH (1976) A theory of optimal capital structure. Bell J Econ 7(1):33-54

Sogorb-Mira F (2005) How SME uniqueness affects capital structure: Evidence from a 1994-1998 Spanish data panel. Small Bus Econ 25:447-457

Stein JC (2003) Agency, information and corporate investment. Handb Econ Finance 1:111-165

Taggart RA Jr (1985) Secular patterns in the financing of U.S. corporations. In: Friedman BM (ed) Corporate capital structures in the United States. University of Chicago Press, New York, pp 13-80

Titman S, Wessels R (1988) The determinants of capital structure choice. J Financ 43(1):1-19

Ur Rehman A, Wang M, Yu H (2016) Dynamics of financial leverage across firm life cycle in Chinese firms: an empirical investigation using dynamic panel data model. China Finance Econ Rev 4(1):19

Uysal VB (2011) Deviation from the target capital structure and acquisition choices. J Financ Econ 102:602-620

Welch I (2004) Capital structure and stock returns. J Polit Econ 112:106-131

Welch I (2007) Common flaws in empirical capital structure research, AFA 2008, New Orleans Meetings Paper

Wiwattanakantang Y (1999) An empirical study on the determinants of the capital structure of Thai firms. Pac Basin Financ J 7:371-403

Yau J, Lau E, Liwan A (2008) Do Malaysian firms practice the pecking order theory in their capital structure? Proceedings of the MFA Conference 2008, Malaysia

Submit your manuscript to a SpringerOpen ${ }^{\circ}$ journal and benefit from:

- Convenient online submission

- Rigorous peer review

- Open access: articles freely available online

- High visibility within the field

Retaining the copyright to your article

Submit your next manuscript at $>$ springeropen.com 